\title{
3D Printing in Medicine for Preoperative Surgical Planning: A Review
}

\author{
A. Tejo-Otero ${ }^{a^{*}}$, I. Buj-Corral ${ }^{b}$, F. Fenollosa-Artés ${ }^{a, b}$ \\ ${ }^{a}$ Centre CIM, Universitat Politècnica de Catalunya (CIM UPC), Carrer de Llorens i Artigas, 12, 08028 , \\ Barcelona, Spain \\ ${ }^{b}$ Universitat Politècnica de Catalunya. Departament of Mechanical Engineering. School of Engineering of \\ Barcelona (ETSEIB). Av. Diagonal, 647. 08028, Barcelona, Spain
}




\section{Abstract}

The aim of this paper is to review the recent evolution of Additive Manufacturing (AM) within the medical field of preoperative surgical planning. The discussion begins with an overview of the different techniques, pointing out their advantages and disadvantages as well as an in-depth comparison of different characteristics of the printed parts. Then, the state-of-the-art with respect to preoperative surgical planning is presented. On the one hand, different surgical planning prototypes manufactured by several AM technologies are described. On the other hand, materials used for mimicking different living tissues are explored by focusing on the material properties: elastic modulus, hardness, etc. As a result, doctors can practice before performing surgery and thereby reduce the time needed for the operation. The subject of patient education is also introduced. A thorough review of the process that is required to obtain 3D Printed surgical planning prototypes, which is based on different stages, is then carried out. Finally, the ethical issues associated with 3D printing in medicine are discussed, along with its future perspectives. Overall, this is important for improving the outcome of the surgery, since doctors will be able to visualize the affected organs and even to practice surgery before performing it.

\section{Keywords}

Additive manufacturing, $3 D$ printing, preoperative, surgical planning, biomaterials, bioengineering, 


\section{Introduction}

Additive Manufacturing (AM), the industrial version of 3D printing, can be defined as the process of joining materials to manufacture objects from a 3D model data, normally layer-upon-layer (each one has a thickness of 0.001 to 0.1 inch ${ }^{148}$ ), by means of a series of some cross-sectional slices as opposed to subtractive manufacturing technologies ${ }^{161}$. There are different technologies within additive manufacturing ${ }^{51}$. Some are easy-to-use "personal" 3D printing machines which can be used in either a home or work environment since they are both low-cost and simple to use. Others, however, are normally more suitable for use in industry. They are larger machines and also capable of meeting different user requirements. Consequently, although more expertise is required to operate them, they offer a wider variety of possible results and effects.

There is a large range of materials that can be used in additive manufacturing: plastics, rubbers, ceramics, glass, metals, etc. ${ }^{58}$. Moreover, it can be used in different fields such as medicine (implants, anatomical models, tissue engineering) or industry (working tools, personalized molds).

AM has existed for over 30 years ${ }^{10}$; however, its popularity with both the public and the experts has grown mainly in recent years. The first steps were taken during the early 80 s with Mr. Komada who invented two different methods of producing 3D plastic models with photo-hardening thermoset polymer ${ }^{76}$. He stated it was a patent without sense, so he did not patent it. Then, in 1984, JeanClaude André, Alain La Mehauté and Olivier de Witte made a device which produces a model of an industrial part ${ }^{6}$. However, it was rejected due to the "lack of marketing perspectives".

Subsequently, SLA (stereolithography) was patented by Charles W. Hull (3DSystems) ${ }^{64}$ in 1986. Moreover, he made another contribution by introducing the STL (Standard Triangle Language) format. The following year, Dr. Deckard developed the SLS (Selective Laser Sintering) ${ }^{37}$, although it would not be marketed until 1992. In 1989, Scott Crump, co-founder of Stratasys, patented the FDM (Fused Deposition Modelling) ${ }^{33}$, which did not expire until 2009. From that point, this technology has also been known as FFF (Fused Filament Fabrication) and has grown steadily as an open source technology.

In recent years, these AM technologies have evolved, and new ones have appeared. ISO/ASTM 52900 Standard ${ }^{161}$ classifies all technologies in seven categories: binder jetting, direct energy deposition, material extrusion (includes FFF), material jetting, powder bed fusion (includes selective laser sintering), sheet lamination and vat photopolimerisation (includes stereolithography).

As a result, medicine has undergone an important transformation, as this technology allows manufacturing high quality surgical planning prototypes that reproduce soft living tissues for preoperative surgical planning ${ }^{149}$. For instance, it can be used to obtain liver or brain surgical planning prototypes. Therefore, it 
is necessary to analyze the patients by carrying out a variety of different imaging techniques in order to build their physical model. In this way, the doctors have a better idea of what to expect and can improve their procedure. There are also savings in both cost and time, and it helps to achieve improvements in the processes ${ }^{68}$.

Therefore, this review aims to discuss the state-of-the-art with preoperative surgical planning. Firstly, there is an overview of the current 3D printing technologies used in medicine as well as an in-depth comparison of important aspects of the printing technologies is presented. This is followed by a description of the research done for preoperative surgical planning and patient education. Then, the process of $3 \mathrm{D}$ printing in preoperative surgical planning, with its different stages, is thoroughly explained. And last but not least, the ethical issues are discussed, as well as future prospects.

\section{Current 3D Printing Technologies in Medicine}

Surgical planning is an important but not the only application that AM can be used in medicine ${ }^{3}$. For example, cell bioprinting ${ }^{104}$, metallic internal implants ${ }^{70}$, scaffolds ${ }^{22,112}$ etc. There is a wide range of applications, each one using different AM technologies.

Within the medical field, the major 3D printing methods are the following 99,126 :

- Material extrusion with polymeric filaments: Fused Filament Fabrication (FFF) and pastes (commonly ceramics) by robocasting or Direct Ink Writing (DIW).

- Material jetting: Laser-Assisted Bioprinting (LAB), inkjet, jetted photopolymer.

- Powder Bed Fusion (PBF): using polymers and metals, the latter using laser or electron beam as the energy source to melt them.

- Vat photo polymerisation: using upward or downward platforms and laser or other UV light emitting systems (Digital Light Processing -DLP-, Liquid Crystal Display -LCD-...) to photo activate and thus solidify the resin.

It is also worth highlighting that, depending on the possibility of printing cells in the structure, two different categories can stand out (Figure 1) depending on their main applications. 


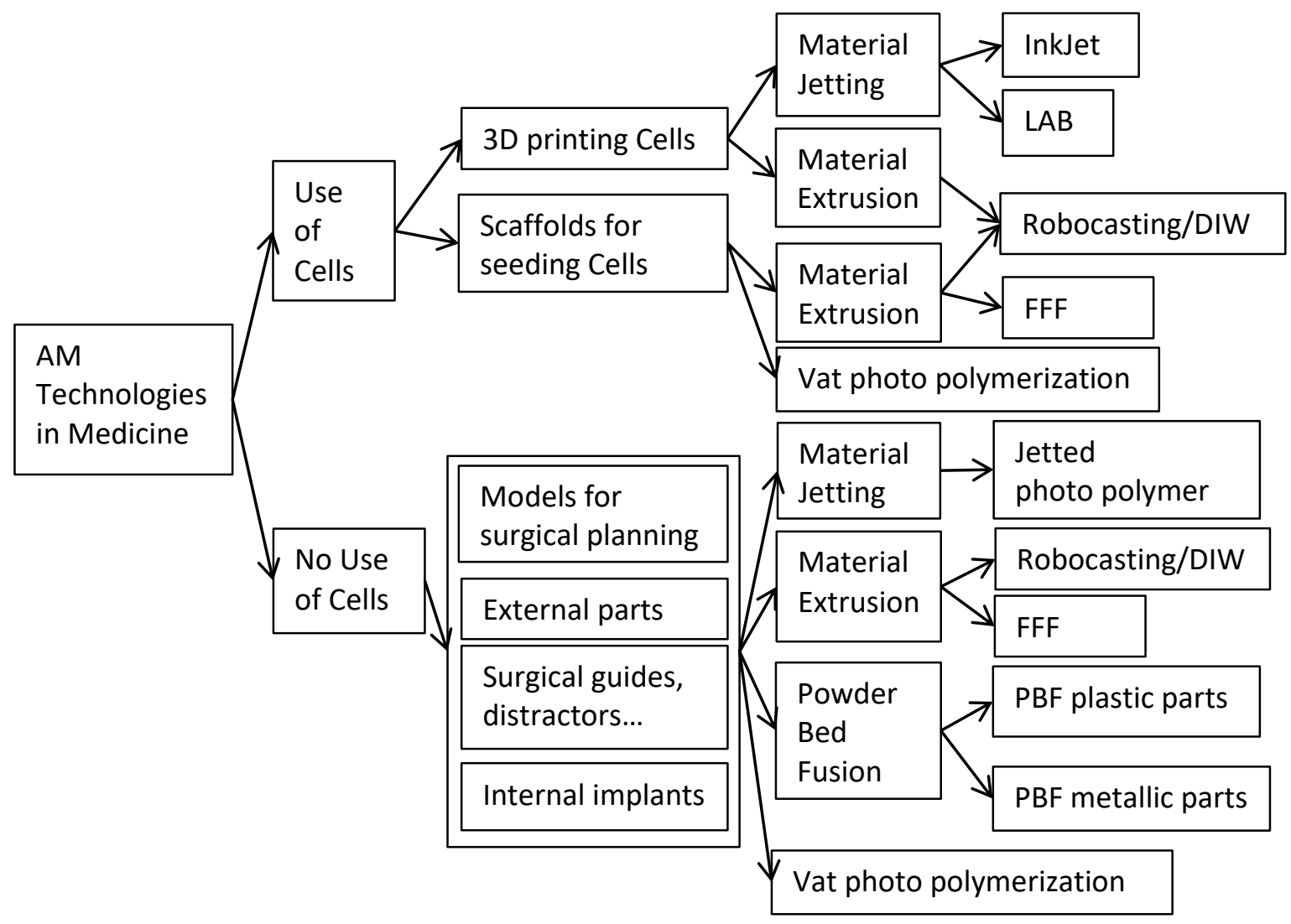

Figure 1. Diagram of the different AM technologies in medicine.

In these techniques, there are some important parameters to be taken into consideration: cell viability and density, resolution, fabrication speed, accuracy, cost, processing mode, viscosity, hardness and ultimate strength.

Regarding surgical planning, the main techniques used for the manufacturing of the surgical planning prototypes are: (1) material extrusion by FFF and DIW (Direct Ink Writing); (2) PBF for plastic parts; (3) SLA; and (4) material jetting. 


\subsection{D Printing Techniques That Use Cells}

\subsubsection{Material Extrusion by Robocasting/Direct Ink Writing (DIW) and FFF}

Materials extrusion by Robocasting or DIW is a 3D printing technique in which 3D structures are built by forcing material and/or cells through a nozzle onto layerupon-layer stages ${ }^{32}$ with a continuous deposition ${ }^{75}$. The dispensing can be done in three ways (Figure 2):

1) Pneumatic dispensing is based on the air pressure providing the driving force.

2) Piston dispensing is a vertical displacement.

3) Screw dispensing is based on a rotation.

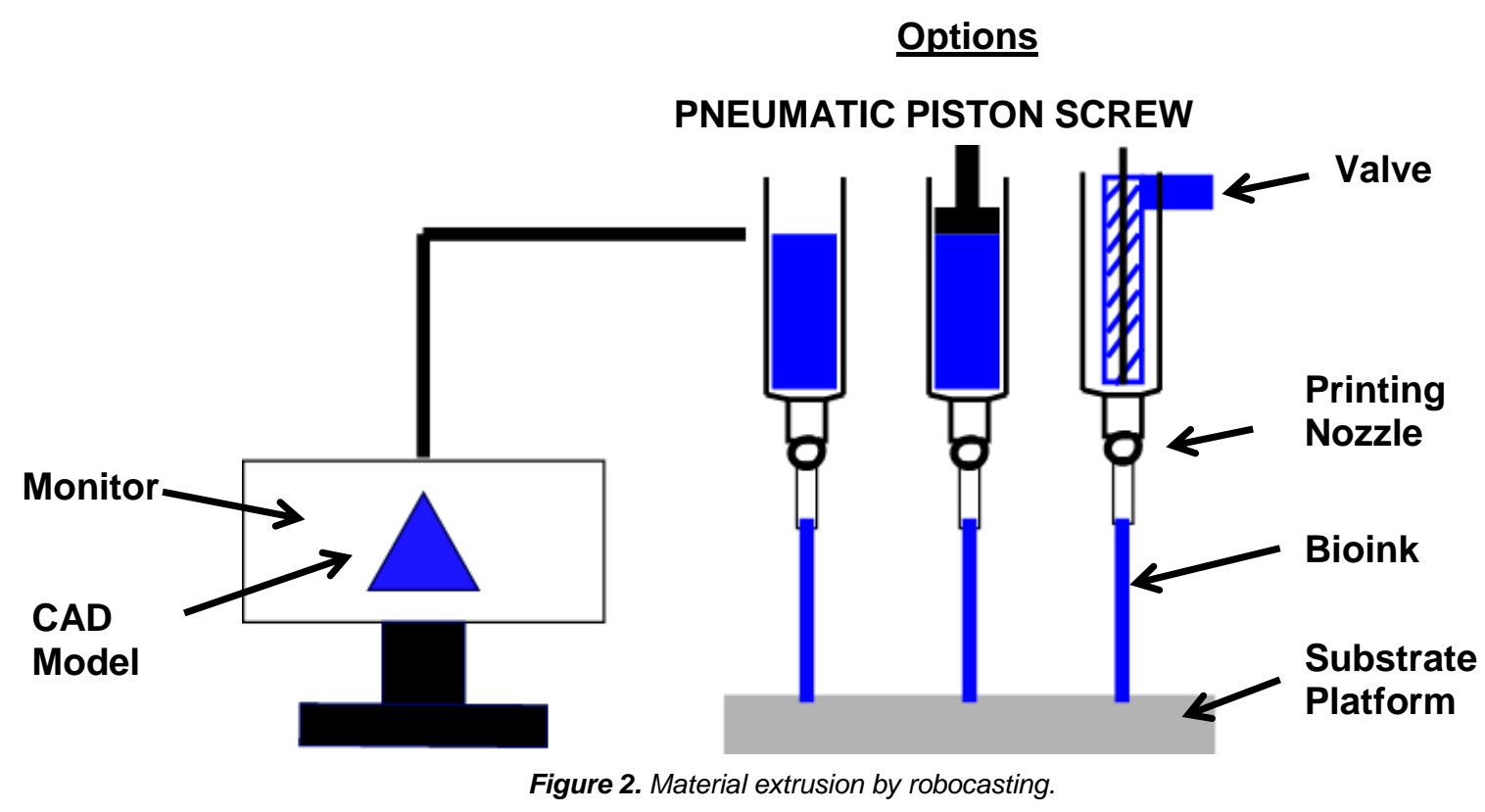

The advantages and disadvantages of material extrusion stated in Table 1.

Table 1. Advantages and disadvantages of material extrusion by robocasting ${ }^{35,99,108}$.

\begin{tabular}{|cc|}
\hline Advantages & Disadvantages \\
\hline Simple & Expensive and low accuracy \\
\hline Wide range of materials & Supports are required \\
\hline Multiple compositions of materials & Shear stress on nozzle tip wall \\
\hline Good mechanical properties & Sintering is required in some cases \\
\hline
\end{tabular}

At the moment, the extruded materials are deposited in two ways: (1) moving the nozzle above the stage; or (2) moving the stage underneath the nozzle

Furthermore, Fused Filament Fabrication (FFF) can be highlighted in material extrusion, as a process that uses a continuous filament of a thermoplastic material such as PolyLactic Acid (PLA). 


\subsubsection{Materials Jetting by Inkjet Printing}

Inkjet printing is a non-contact reprographic technique in the substrate is manufactured using ink drops ${ }^{95}$. This is the largest and most common inkjet printing method known as drop-on-demand (DOD). There are also two other groups: continuous-inkjet printing and electro-hydrodynamic jet printing.

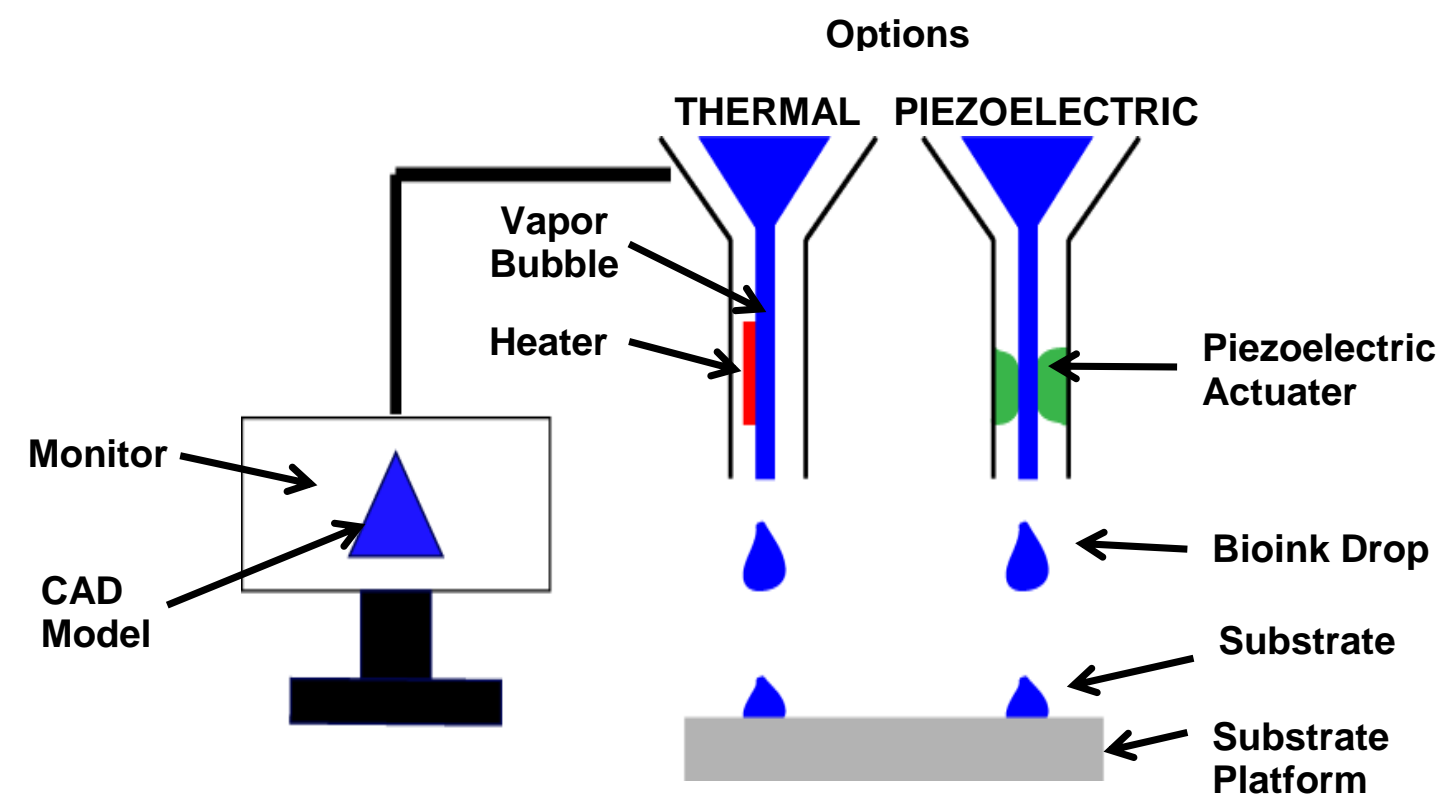

Figure 3. Material jetting by inkjet printing process.

In drop-on-demand printing, two types of heads can be used to eject drops of liquid onto the substrate (Figure 3). Thermal heads use heating forces ${ }^{34}$ which raise the temperature (Table 2). On the other hand, piezoelectric heads use acoustic forces ${ }^{152}$ to change the material shape-(Table 3).

Table 2. Advantages and disadvantages of thermal inkjet printing ${ }^{93}$.

\begin{tabular}{|cl|}
\hline Advantages & \multicolumn{1}{c|}{ Disadvantages } \\
\hline High availability & Low droplet directionality \\
\hline High printing speed & Non-uniform droplet size \\
\hline Low cost of parts fabrication & \\
\hline
\end{tabular}

Table 3. Advantages and disadvantages of piezoelectric inkjet printing ${ }^{93}$.

\begin{tabular}{|cl|}
\hline Advantages & Disadvantages \\
\hline Uniform droplet size & Nozzle clogging \\
\hline Uniform ejection directionality & \\
\hline
\end{tabular}




\subsubsection{Material Jetting by Laser-Assisted Bioprinting (LAB)}

This method is based on the Laser-Induced Forward Transfer (LIFT) introduced by Bohandy et al. ${ }^{20}$. It is a non-contact direct-write technique which enables the deposition of small volumes of materials ${ }^{60}$. It has been extensively used as a method of additive micropatterning materials like metals ${ }^{12}$, but here it is applied to settle bioinks (Figure 4).

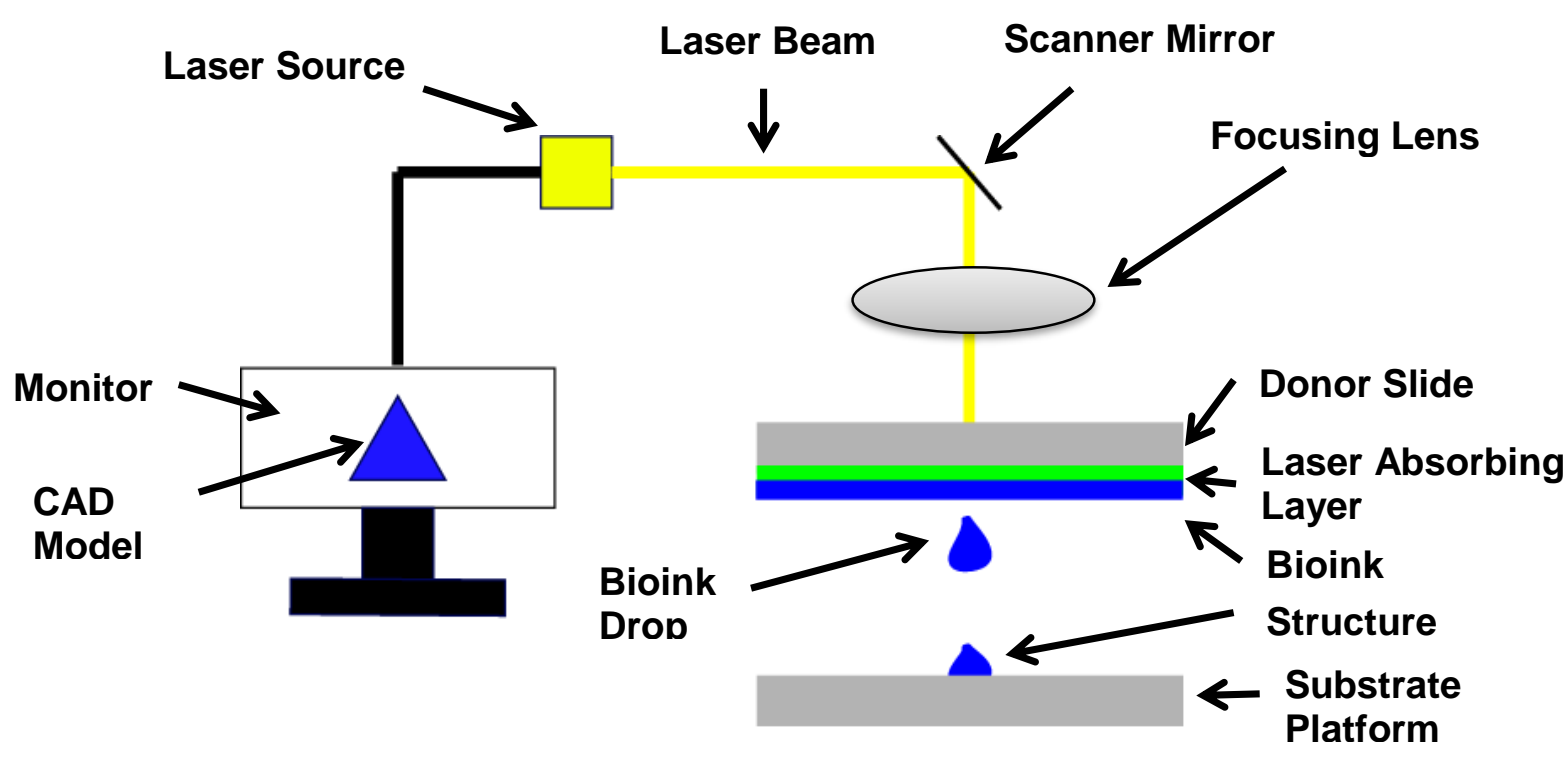

Figure 4. Laser-assisted bioprinting (LAB) process.

The process is as follows ${ }^{137}$ : the laser beam is focused perpendicularly onto the thin film, called donor, which is locally heated. Then, a small high pressure generated vapor bubble forces the bioink onto the substrate, known as the receiver. LAB also has its advantages and disadvantages, as seen in Table 4.

Table 4. Advantages and disadvantages of laser-assisted bioprinting ${ }^{99}$.

\begin{tabular}{|cc|}
\hline Advantages & Disadvantages \\
\hline High resolution & Low printing speed \\
\hline Compatible with a wide range of viscosities & High cost \\
\hline High accuracy & \\
\hline
\end{tabular}




\subsection{D Printing Techniques That Do Not Use Cells}

\subsubsection{Vat Photopolymerization by Stereolithography (SLA)}

Vat photopolymerization by stereolithography (SLA) is an additive manufacturing method that uses a laser technology which is based on the spatially controlled solidification of a liquid resin by photopolymerization ${ }^{45}$.

At the beginning of the process, a thin layer of the material above the movable platform (moving vertically) is exposed to a UV laser. This hardens it to form the first layer of the 3D printed object. At the moment the UV laser traces the section, it instantly bonds to the one beneath it. This process is carried out repeatedly until the piece is completed. Finally, the platform is raised in order to expose the final product, which must then be post-cured (Figure 5).

The advantages and disadvantages of SLA can be seen in Table 5.

Table 5. Advantages and disadvantages of stereolithography $29,32,45,63,74$.

\begin{tabular}{|cc|}
\hline Advantages & Disadvantages \\
\hline $\begin{array}{c}\text { Speed, pieces can be manufactured } \\
\text { within hours or a day }\end{array}$ & $\begin{array}{c}\text { Expensive technology: SLA machine } \\
\text { can cost 250.000 } \$\end{array}$ \\
\hline $\begin{array}{c}\text { Optimal mechanical features, so } \\
\text { they can resist machining }\end{array}$ & $\begin{array}{c}\text { Photopolymers are sticky, messy and } \\
\text { need to be handled carefully }\end{array}$ \\
\hline Good surface finish & Printed parts need to be cured \\
\hline Complex geometries & Supports are required \\
\hline
\end{tabular}

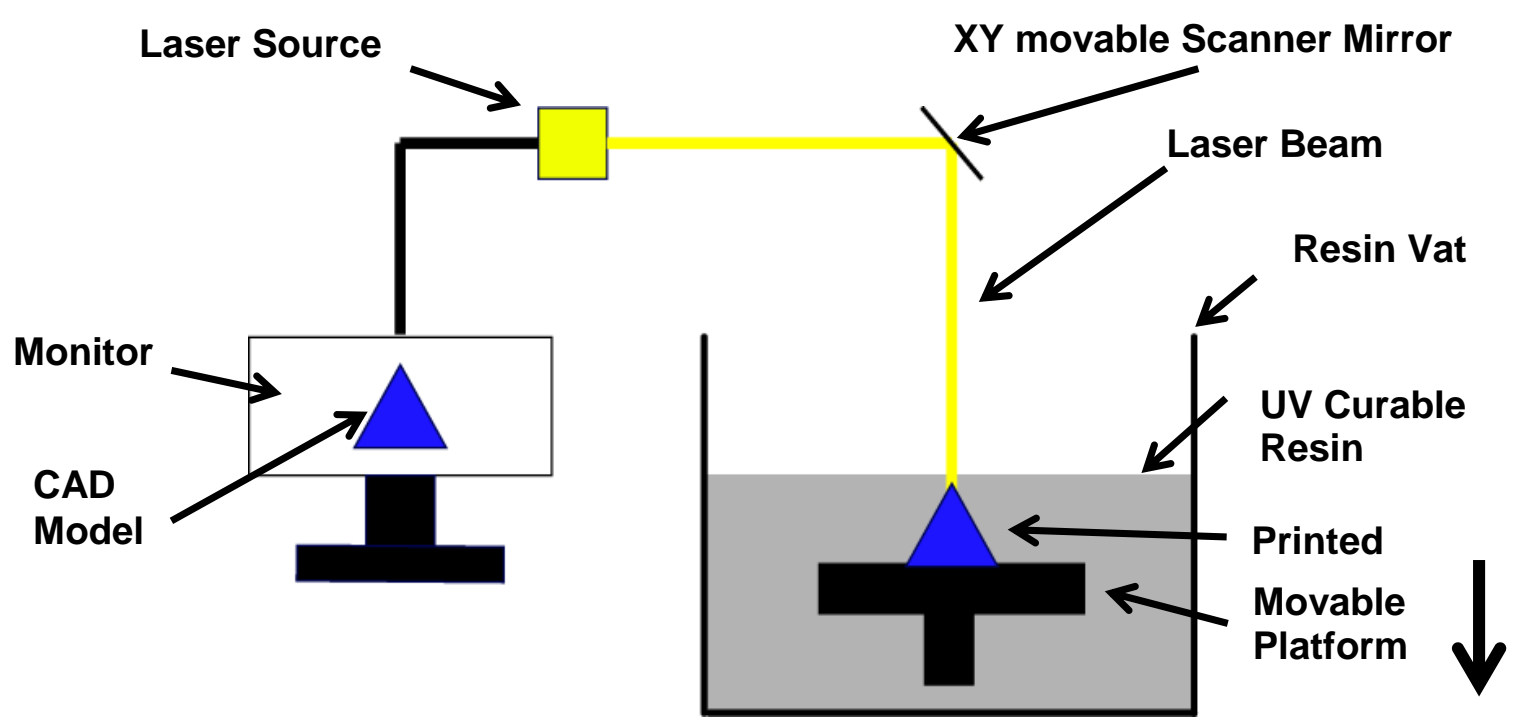

Figure 5. Stereolithography process (downward platform). 


\subsubsection{Powder Bed Fusion for Plastic Parts}

Powder Bed Fusion (PBF) is a rapid prototyping technique which uses a heat source to create 3D objects layer-by-layer from powdered materials. In the case of Selective Laser Sintering (SLS), the heat to melt thermoplastics is generated by a $\mathrm{CO}_{2}$ laser ${ }^{59}$.

The details of the most common process, SLS related to PBF, are as follows 59 : the machine begins with the production of the first layer onto the powder bed with the delivery by roller of a very thin layer of a heat-fusible powder. Then, a heatgenerating $\mathrm{CO}_{2}$ laser beam scans across this layer, drawing the cross-section on the material. After that, the platform is slightly lowered and another thin layer of powder is deposited. This process is repeated continuously, layer-by-layer, until the desired object is completed (Figure 6).

The advantages and disadvantages of PBF for plastics can be seen in Table 6.

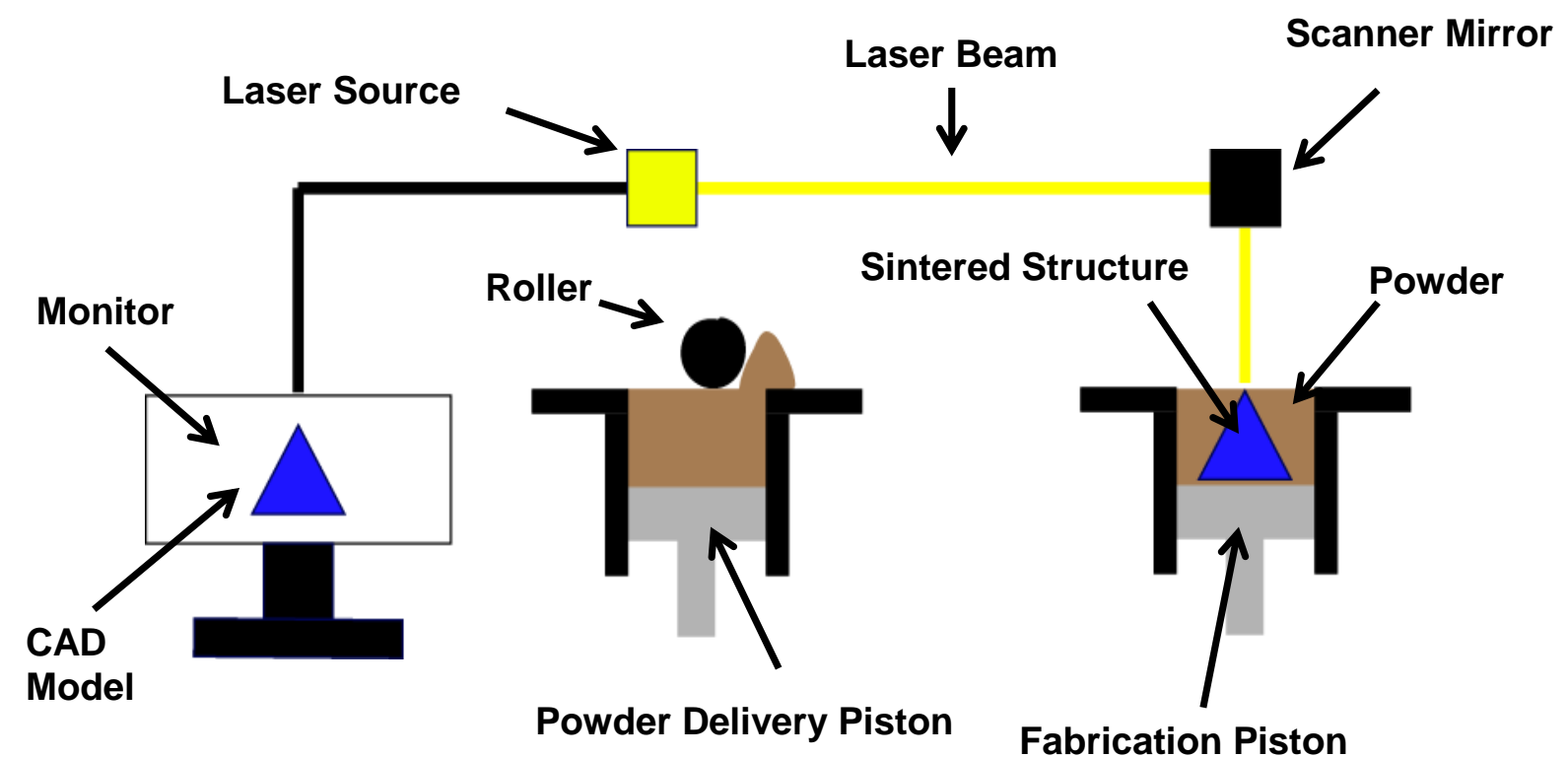

Figure 6. Powder Bed Fusion for plastic parts process.

Table 6. Advantages and disadvantages of powder bed fusion for plastic parts ${ }^{11,47,59,90}$.

\begin{tabular}{|cc|}
\hline Advantages & Disadvantages \\
\hline Shorten design-manufacturing cycle & Porous surfaces \\
\hline Increase competitiveness & Expensive material and equipment \\
\hline $\begin{array}{c}\text { Produced objects are light-weight, } \\
\text { durable and have heat and chemical } \\
\text { resistance }\end{array}$ \\
\hline The flexibility of the material & \\
\hline Supports are not required & \\
\hline
\end{tabular}




\subsubsection{Powder Bed Fusion for Metallic Parts}

Powder Bed Fusion (PBF) is also used with metallic powders to form very strong parts, such as customized artificial knees and ankles. As an energy source, it uses a scanning laser or an electron beam to melt different layers of powdered metals so as to produce functional metallic prototypes, parts or tools ${ }^{80,84}$.

The most common process is Selective Laser Melting (SLM), related to PBF in metallic parts, which takes place inside a closed chamber. This is filled with an inert gas such as $\mathrm{N}_{2}$ or $\mathrm{Ar}^{54}$. The process starts with the deposition of a thin layer of powder over a substrate plate, which is then melted by the laser beam. Then, another thin layer of the powder is deposited onto the previous layer; the laser then melts and fuses the powder particles selectively, according to the CAD file. This process is repeated until the product is finished (Figure 6). In this case, the material is melted instead of sintered.

The advantages and disadvantages of PBF for metallic parts can be seen in Table 7.

Table 7. Advantages and disadvantages of PBF for metallic parts ${ }^{54}$.

\begin{tabular}{|cc|}
\hline Advantages & Disadvantages \\
\hline Large range material & Slow process \\
\hline Increased functionality & High cost \\
\hline & Powder handling can be awkward; \\
security issues \\
\hline
\end{tabular}




\subsection{Comparison of the 3D Printing Technologies in Medicine}

Before any model is 3D printed, it is necessary to take different factors into consideration. In other words, depending on the aim of the experiment, the material used, etc., it might be better to use one technology or another. Moreover, it is necessary to know in advance if the use of cells will be compulsory or not. Therefore, it is important to highlight different aspects of the AM technologies explained above (Table 8).

Table 8. Comparison of the 3D printing technologies in medicine.

\begin{tabular}{|c|c|c|c|c|c|c|c|}
\hline Technology & SLA & FFF/Robocasting & Inkjet & LAB & $\begin{array}{c}\text { PBF } \\
\text { Plastics }\end{array}$ & PBF Metals & References \\
\hline Cell viability & High (>95\%) & Medium (40-80\%) & High (>85\%) & High (>95\%) & $\begin{array}{c}\text { High } \\
(>85 \%)\end{array}$ & High (>85\%) & $23,40,79,86,114,143,151$ \\
\hline Cell density & Medium & High & Low & Medium & High & High & $34,57,86,99,143156$ \\
\hline Resolution & $\begin{array}{c}\text { Medium-low } \\
(100 \mu \mathrm{m})\end{array}$ & $\begin{array}{c}\text { Medium-low } \\
(100 \mu \mathrm{m})\end{array}$ & Medium $(50 \mu \mathrm{m})$ & High $(10 \mu \mathrm{m})$ & $\begin{array}{c}\text { Medium } \\
(50 \mu \mathrm{m})\end{array}$ & $\begin{array}{c}\text { Medium-low } \\
(100 \mu \mathrm{m})\end{array}$ & $39,40,50,56,57,109$ \\
\hline $\begin{array}{c}\text { Manufacturing } \\
\text { speed }\end{array}$ & $\begin{array}{c}\text { Fast } \\
(1.5 \mathrm{~cm} / \mathrm{h})\end{array}$ & $\begin{array}{l}\text { Slow }(10 \mu \mathrm{m}- \\
50 \mathrm{~mm} / \mathrm{s})\end{array}$ & $\begin{array}{c}\text { Fast }(1-10000 \\
\text { droplets/s) }\end{array}$ & $\begin{array}{c}\text { Medium-fast } \\
(100- \\
1600 \mathrm{~mm} / \mathrm{s}) \\
\end{array}$ & $\begin{array}{l}\text { Medium- } \\
\text { fast } \\
(127 \mathrm{~mm} / \mathrm{s}) \\
\end{array}$ & Slow $(15 \mu \mathrm{m})$ & $40,55,99,125,127$ \\
\hline Accuracy & High & Medium-low & Medium & High & High & High & $32,40,102$ \\
\hline Cost & Low & Moderate & Low & High & Moderate & Moderate & $19,40,54$ \\
\hline $\begin{array}{l}\text { Processing } \\
\text { mode }\end{array}$ & UV laser & $\begin{array}{l}\text { Thermal } \\
\text { Mechanical } \\
\text { Chemical }\end{array}$ & $\begin{array}{l}\text { Thermal } \\
\text { Mechanical }\end{array}$ & Optical & $\begin{array}{c}\text { Heat- } \\
\text { generating } \\
\mathrm{CO}_{2} \text { laser } \\
\text { beam }\end{array}$ & Laser beam & $35,40,45,86,143$ \\
\hline Viscosity & No limitation & $\begin{array}{c}\text { High }\left(30-6 \times 10^{7}\right. \\
\text { mPa*s) }^{*} \mathrm{~s}\end{array}$ & $\begin{array}{c}\text { Low }(<10 \\
\left.\mathrm{mPa}^{*} \mathrm{~s}\right)\end{array}$ & $\begin{array}{l}\text { Medium (1- } \\
\left.300 \mathrm{mPa}^{*} \mathrm{~s}\right)\end{array}$ & $\begin{array}{l}\text { Low }(0.9- \\
\left.1.6 \mathrm{mPa}^{*} \mathrm{~s}\right)\end{array}$ & $\begin{array}{c}\text { High } \\
\left(8 \times \mathrm{Pa}^{*} \mathrm{~s}\right)\end{array}$ & $42,106,132$ \\
\hline Hardness & Shore A-D & Shore A - D & Shore 00 - A & $10-80$ Shore A & Shore A - D & $\begin{array}{c}200-750 \\
H V\end{array}$ & $30,31,41,46,88,115,142,155$ \\
\hline
\end{tabular}




\section{Preoperative Surgical Planning}

In 2015, in the United States of America, 121,070 people required an organ transplant. Nonetheless, only 2,553 were performed in that year and approximately 22 people die daily while waiting ${ }^{66}$. Every 15 minutes another person is added to the organ transplant waiting list ${ }^{1}$. Moreover, the population is aging, and consequently it is very likely that considerably more organs operations will be needed. Therefore, it is extremely important to be prepared. Further development in the use of additive manufacturing techniques is necessary to improve the surgeons' preoperative performance, leading to better and faster operations.

The surgeons only have a short period of time during the operation to carry out complex technical tasks. Hence, it could be vital to know beforehand what exactly has to be done, for two reasons: (1) operation time would be decreased; (2) the risks could be reduced. However, to date doctors have not received enough training and methods to face this problem ${ }^{26}$.

It has been demonstrated in different studies that surgeons who trained with physical models or surgical planning prototypes, known as phantoms (simulated biological bodies ${ }^{67}$ ), had better skills in comparison with those who did not have the same opportunity ${ }^{118}$. One of the skills improved is application of the correct amount of force, since surgical simulation revealed that more than a $50 \%$ of errors are attributable to excessive force ${ }^{134}$. In general, novice surgeons apply more force than they should in comparison with experienced surgeons. Considering the data ${ }^{129}$, the average force applied is mainly around $0.5 \mathrm{~N}$, although at specific moments, such as gripping tumor tissue, it might reach $1.25 \mathrm{~N}$. Phantoms are also used for training future doctors in Medical Schools. As it is not always possible to practice with real human bodies, using phantoms can provide an excellent solution.

Regarding preoperative surgical planning, the surgical planning prototypes are manufactured for two reasons:

1. Visualization: these prototypes are manufactured in order to give the surgeon an idea of what to expect. In addition, these prototypes can be sterilized and introduced in the operation room for last-minute inquiries.

2. Mimicking living tissues: these prototypes are for preoperative surgical planning, in other words, for preparing the surgery. For that, the materials need to mimic the correspondent soft living tissue as closely as possible. However, as most of the materials used in this case are hydrogels, there will not be any chance to introduce it in the operation room. 


\subsection{Visualization for Preoperative Surgical Planning}

The prototypes that are used just for visualization do not need to achieve a matching in the mechanical properties of the soft living tissue and the material. However, if the prototype is introduced into the operation room, it needs either to be sterilized or left far from the sterilized surgery area.

Generally, surgical planning prototypes are additive manufactured using PA12 printed by SLS; filaments extruded by FFF and silicones extruded by DIW; resinbased polymers printed by SLA; and finally, liquid photopolymers drop printed by material jetting, and then cured by UV light;

Both steam sterilization by autoclave $\left(121^{\circ} \mathrm{C}\right)$ and ethylene oxide are used for prototypes done in SLS. Also, according to Lucas et al. ${ }^{78}$, Steam Formaldehyde at $60-80^{\circ} \mathrm{C}$ can also be used for prototypes manufactured by SLS. This sterilization technique can also be applied to material jetting ${ }^{78}$. On the other hand, filaments are deformed if they are subjected to high temperature (more than 60 $\left.{ }^{\circ} \mathrm{C}\right)$ and, therefore, ethylene oxide (EtO) or gamma radiation are the best options 121,163. Then, regarding the silicones extruded by DIW, their properties change if they are subjected to conventional high temperatures. Therefore, EtO would be the most effective sterilization method ${ }^{162}$. Finally, regarding SLA, in Robles et al. 89 hydrostatic pressure (HHP) showed more potential to be used in SLA than autoclave for SLA printed materials.

In the next lines, surgical planning prototypes examples using different technologies are described.

\subsubsection{PBF for Plastics Parts}

Powder bed fusion for plastic parts cannot manufacture multi-material pieces. In other words, the SLS only manufactures one material, which is normally PA12; but in this case, polypropylene (PP) was used. Therefore, the only way to distinguish the different anatomical structures is to color the parts before the surgery. See Figure 7.

In another example, Kappanayil et al. ${ }^{71}$, five patients with complex CHD (Congenital Heart Diseases) were chosen for a cardiac MRI assessment and the manufacturing of $3 \mathrm{D}$ prototypes of their structural heart diseases. For the first patient, the 3D physical model of the heart was manufactured by SLS using PP. This model was identical to the original anatomy of the heart. By this way, the prototype helped to visualize the location and size as well as the shape of VSD (Ventricular Septal Defect). 


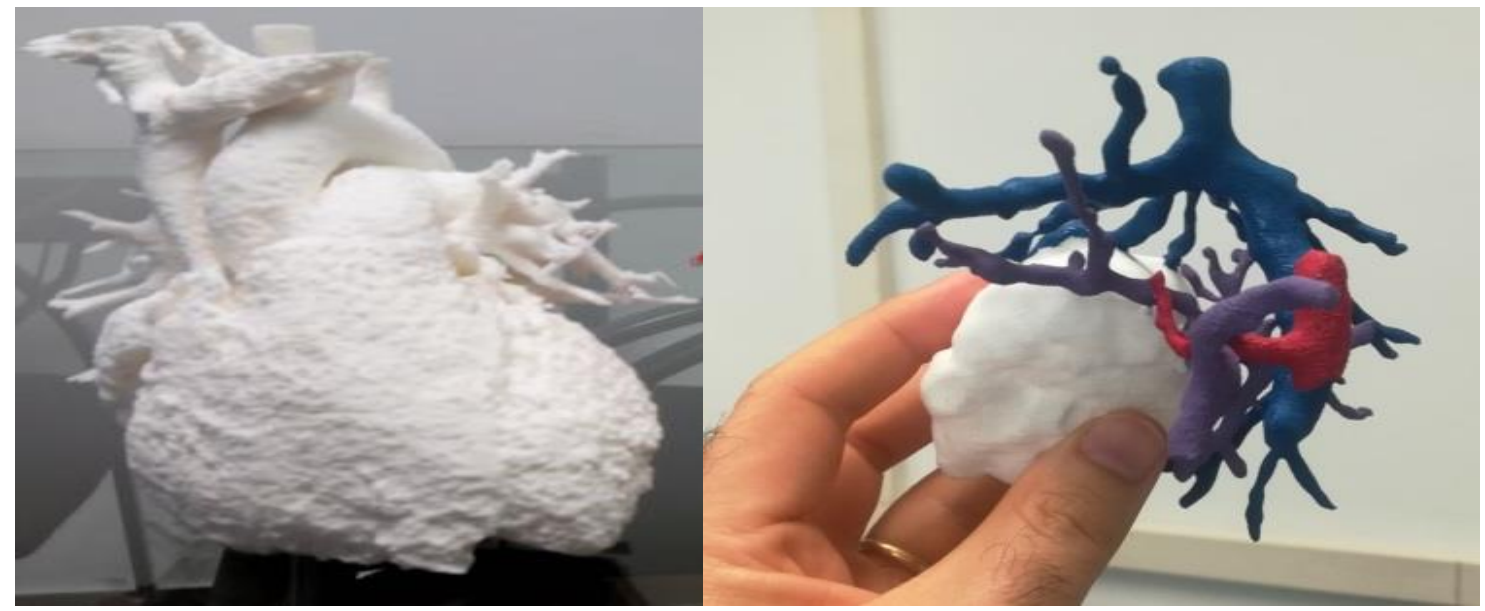

Figure 7. (A) A heart with the different blood vessels printed using the Ricoh AM S5500P (SLS technology) at CIM UPC ${ }^{130}$. (B) The blood vessels and the tumor for a surgical planning prototypes $3 D$ printed using the SLS technology. They were colored so as to be easier for the surgeon to distinguish the different anatomical structure.

Powder bed fusion for plastic parts was also used with the molding technique. Molding is the additive manufacturing process by which a mold is manufactured by FFF using a rigid filament, normally PLA; and then a liquid (silicone or hydrogel) is cast inside the mold. This method was also used in 65,98,147. Transparent silicones must be used so that the inner parts of the surgical planning prototype are visible. See Figure 8 . Additionally, the use of silicones has the advantage of being inert ${ }^{49}$. By this way, it does not decompose and can be used for a long period of time. For example, after being used in the operation room, it can be used for educating future students of the Medical School.

(A)

(B)

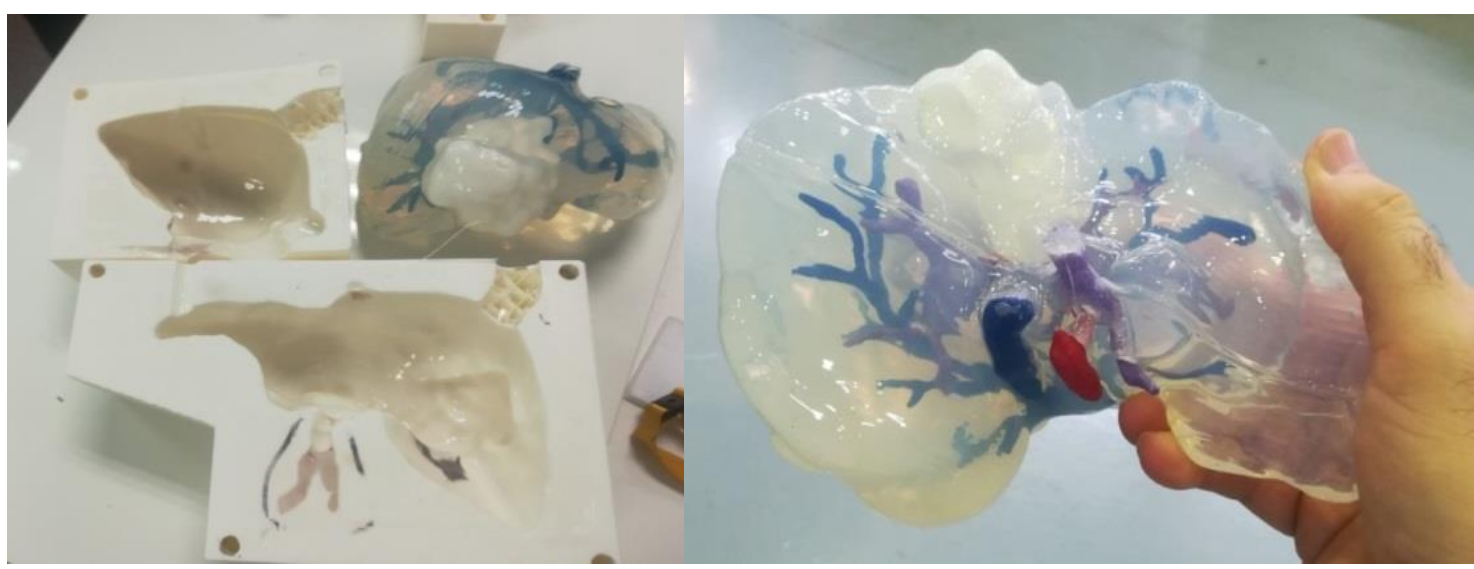

Figure 8. (A) The mold for the surgical planning prototype was manufactured using PLA as material and a FFF BCN3D 3D printer. (B) The surgical planning prototype which is a liver (the silicone (38 Shore $A$ silicone) with the blood vessel in different colors (blue, red and purple) and the tumor in white color manufactured by using the Ricoh AM S5500P (SLS technology) at CIM UPC. 
These prototypes are low-cost, since the FFF technology is not expensive. However, these prototypes, manufactured by FFF using PLA filaments, are mainly for visualization. In addition, as can be seen, it is more difficult to distinguish the different anatomical structures using a mono-material prototype (Figure 9A) than in multi-color prototypes (Figure 9B). Therefore, it is better to use at least two different colors.

(A)

(B)

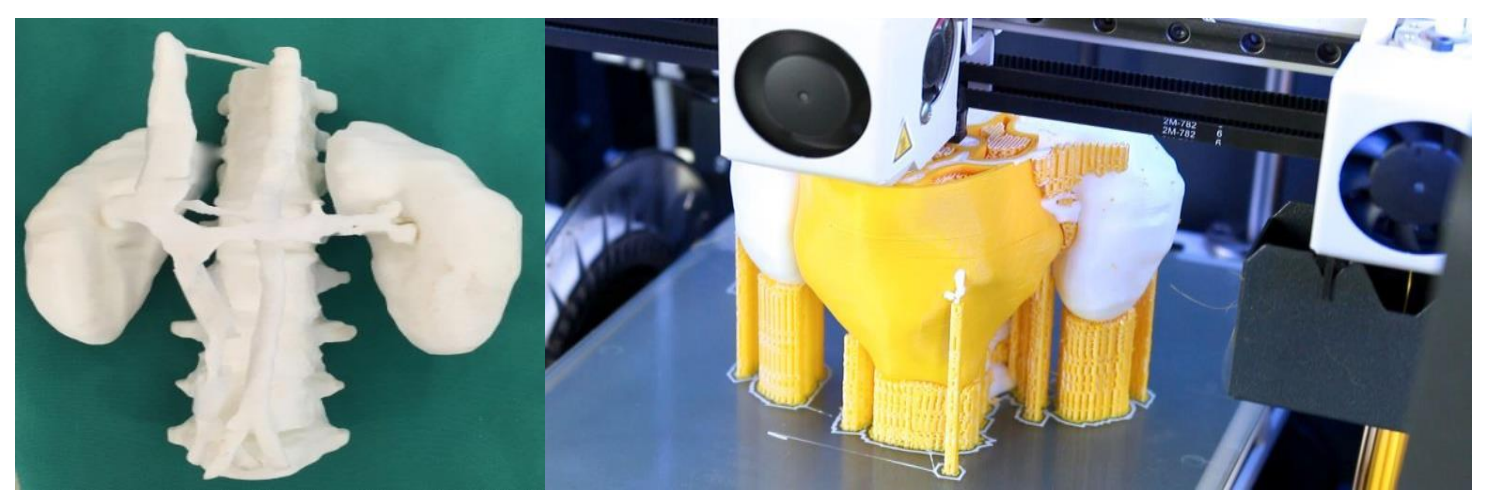

Figure 9. (A) The surgical planning prototype without tumor was manufactured by FFF using Filaflex®. (B) A BCN3D Sigma (BCN3D Technologies from Barcelona), which is an IDEX (Independent Dual Extruders) printer at CIM UPC. The yellow color was used for the tumor and supports and the white for the organs.

Another study which used PLA filaments was Anderson et al. ${ }^{5}$. They manufactured a 3D printed hollow intracranial aneurysm model with rigid walls. Additionally, one important application of these models is their use in MRI flow phantoms. By his way, it is possible to stablish an imaging protocol for visualizing and quantifying aneurysm hemodynamics.

ABS filaments can also be used as done in Faroogi et al. ${ }^{43}$. In this study, 3D printed cardiac models were manufactured for the preoperative planning surgery of adults with congenital cardiac disease and heart failure. 


\subsubsection{SLA}

Regarding SLA, in 2004 an accurate, life-sized, solid surgical planning prototype was manufactured using SLA in order to prepare an operation of conjoined twins 28. They were joined at the head; therefore, it was difficult to determine the perfect course of action. Consequently, a surgical planning prototype was manufactured, making it possible to prepare the operation beforehand and acquire the knowledge to carry out a perfect operation.

Another case of aneurysm was also studied, but in this case SLA was used ${ }^{150}$, instead of FFF for the manufacturing of the 3D physical models. In Wurm et al. 150 a photosensitive polymeric liquid-plastic was used as the material for the prototypes. However, the models were found to be very rigid. Consequently, they were not very helpful for clipping and dissecting exercises. In this case, unlike in Wurm et al. ${ }^{150}$, a 3D heart model was manufactured by SLA and the model offered not only a good anatomy of the heart, but also allowed the doctors to cut and suture in the preoperative surgical planning ${ }^{124}$.

Additionally, in Figure 10, the removal of a tumor can be seen. Two models were manufactured by SLA, before and after the removal of the tumor. This surgery was carried out in the Clinic Hospital of Barcelona and the prototypes were made at CIM UPC. The prototypes helped the surgeons to visualize the tumor and the anatomical reference around it, and guided them during the operation.

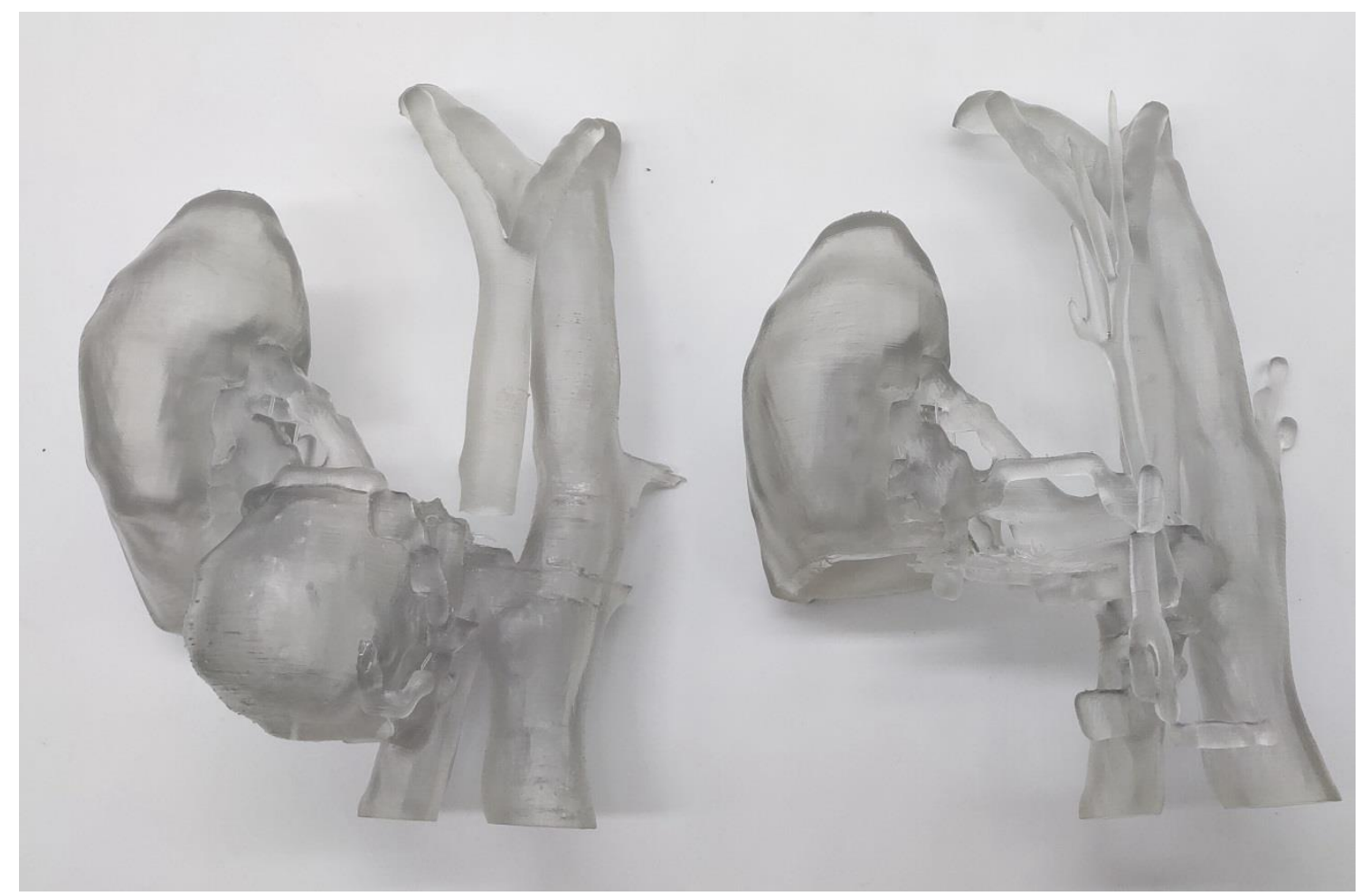

Figure 10. It is a surgical panning prototype used in an operation which aim was to remove the tumor. In the left side, the prototype with the tumor can be seen. In the right side, the tumor after being removed. 


\subsubsection{Material Jetting}

In Zein et al. ${ }^{103}$ a 42-year-old man with cryptogenic liver cirrhosis and a $3 \mathrm{~cm}$ nodule in segment $\mathrm{VI}$ (according to Couinaud's classification) needed a new liver. Therefore, 3D printed liver physical models from donor and the man were manufactured in order to ease the operation. The 3D printed surgical planning prototypes mimicked their corresponding native livers (95\% confidence intervals were reported).

As mentioned with multi-color prototypes in FFF, in Yang et al. ${ }^{153}$ a heart model was manufactured using the Tango family of photopolymers with different colors so as to distinguish the different parts in the heart model. By this way, a better visualization of the heart geometry was achieved using this model.

The idea introduced in Yang et al. ${ }^{153}$ was also applied in Kusaka et al. ${ }^{82}$, but in this case a kidney was 3D printed using Tango family of photopolymers with different colors.

This technique, as opposed to the other three technologies mentioned in this section, can manufacture surgical planning prototypes with different textures (softer or harder), and hence, it is the best for mimicking the 3D physical models. An example of material jetting used for mimicking soft living tissues will be introduced in the next section. 


\subsection{Mimicking Living Tissues for Preoperative Surgical Planning}

Surgical planning prototypes are customized simulated biological bodies whose function is to mimic the organ's properties. The characteristics (Table 9) that are particularly important for the surgeons are elasticity (Young's Modulus), density and shore. Shore hardness is a specific hardness test, often used for soft materials. Shore is the unit used for measuring the hardness, which has 12 different scales according to ASTM D2240 testing standards ${ }^{9}:$ A, B, C, D, DO, E, M, O, OO, OOO, OOO-S, and R. Each scale has values between 0 and 100, with the higher values indicating that a material is harder. Regarding soft living tissues, the main scales are Shore A, Shore 00 and Shore 000 scales; being Shore A the hardest, and Shore 000 the softest.

Table 9. Properties of eleven different organs of the human body ${ }^{44}$.

\begin{tabular}{|c|c|c|c|}
\hline Tissue & $\begin{array}{c}\text { Elastic } \\
\text { Modulus (kPa) }\end{array}$ & Hardness (Shore) & $\begin{array}{c}\text { Density } \\
(\mathbf{k g} \\
\left.\mathbf{c m}^{3}\right)\end{array}$ \\
\hline Lung & 2.85 & $\begin{array}{c}40 \text { Shore OOO - } 10 \text { Shore } \\
\text { OO }\end{array}$ & 394 \\
\hline Liver & 6.55 & $\begin{array}{c}52 \text { Shore OOO - } 25 \text { Shore } \\
\text { OO }\end{array}$ & 1050 \\
\hline $\begin{array}{c}\text { Breast } \\
\text { adipose } \\
\text { tissue }\end{array}$ & 9.90 & $\begin{array}{c}54 \text { Shore OOO - } 35 \text { Shore } \\
\text { OO }\end{array}$ & 911 \\
\hline Kidney & 12.66 & $\begin{array}{c}56 \text { Shore OOO - } 40 \text { Shore } \\
\text { OO }\end{array}$ & 1050 \\
\hline Pancreas & 14.40 & $\begin{array}{c}58 \text { Shore OOO - } 45 \text { Shore } \\
\text { OO }\end{array}$ & 1050 \\
\hline $\begin{array}{c}\text { Breast } \\
\text { fiberglandular } \\
\text { tissue }\end{array}$ & 22.50 & 56 Shore OO - 10 Shore A & 1050 \\
\hline Parotid gland & 31.14 & 60 Shore $\mathrm{OO}-13$ Shore $\mathrm{A}$ & 1050 \\
\hline $\begin{array}{c}\text { White matter } \\
\text { brain }\end{array}$ & 40.80 & hore OO - 20 Shore A & 1050 \\
\hline Breast tumor & 45 & 30 Shore $\mathrm{O}-22$ Shore $\mathrm{A}$ & 1050 \\
\hline Muscle & 49.80 & 35 Shore $\mathrm{O}-25$ Shore $\mathrm{A}$ & 1050 \\
\hline
\end{tabular}

These prototypes are made of different materials, which are able to mimic the living tissues. Many different materials have been studied: PVA (poly (vynil) alcohol), PHY (phytagel), PVC (polyvinyl chloride), agar-agar, gelatin, hydrogels or silicones $2,36,48,85,133$. Hydrogels have become the most popular of these materials because of their biocompatibility ${ }^{4}$, good cell adhesion, migration and proliferation ${ }^{53}$, yet their mechanical properties are not the best ${ }^{107}$. Although cell viability is not a necessary property in organ models for preoperative surgical 
planning, it is known that these phantoms could also be used as scaffolds ${ }^{100}$ for regenerative medicine or tissue engineering.

As the hydrogels offer poor mechanical properties, different polymers are crosslinked so as to achieve better mechanical properties. For instance, in Tan et al. 133 different concentrations of PVA and PHY were used to mimic three different living tissues: brain, lung and liver. To do so, three mechanical measurements were made: true stress at $30 \%$ strain, average insertion force and average friction force. It was concluded that the best compositions for each organ were the following: (1) for the brain, 2.5\%wt PVA + 1.2\%wt PHY; (2) for the lung, 11\%wt PVA; and (3) for the liver, 14\%wt PVA $+2 \% w t$ PHY. The last organ mentioned was also studied in Jong et al. ${ }^{36}$, by focusing on the number of freeze-thaw cycles. It was seen that the 4\%wt PVA with two freeze-thaw cycles could replicate the liver tissue.

Regarding the brain, different types of materials were used in Forte et al. ${ }^{48}$ : PVA, PHY, Sylgard 184 (also known as PDMS-Polydimethylsiloxane-) and Sylgard 527 (silicone elastomer) and gelatin. The first two polymers were combined in a 1:1 ratio so as to form a $\mathrm{CH}$ (composite hydrogel) with 6\%wt PVA + 0.85\%wt PHY. One mechanical test proved that only the $\mathrm{CH}$ was able to reproduce the brain tissue and the concentration of the PVA could be varied from $6 \%$ to $2.25 \%$. A similar result was also obtained in Leibinger et al. ${ }^{85}$ where a 5\%wt PVA + $0.59 \%$ wt PHY could match some of the different characteristics of the brain.

In terms of the kidney, for example, in Adams et al. ${ }^{2}$ different kidney models were created with different materials: silicone, agar, PDMS, TangoPlus ${ }^{\circledR}$ and TangoBlackPlus ${ }^{\circledR}$. Different mechanical properties: shore hardness (the resistance of a sample to local plastic deformation obtained from indentation), elastic modulus (quantifies the stiffness of a sample, in other words, it states if a sample is elastic or not. High elastic modulus corresponds to rigid samples, while low values to elastic samples) and tensile strength (the maximum pulling load that a sample can withstand without breaking) were measured (Table 10).

Table 10. Material properties of the three polymers used to replicate kidney tissue in this study, as well as, TangoPlus $^{\circledR} /$ TangoBlackPlus $^{\circledR}$ (directly 3 D printable elastomers) ${ }^{2}$.

\begin{tabular}{|cccccc|} 
Materials & $\begin{array}{c}\text { Kidney } \\
\text { Tissue }\end{array}$ & $\begin{array}{c}\text { Silicone } \\
\text { elastomer }\end{array}$ & Agarose (4\%) & PDMS & $\begin{array}{c}\text { TangoPlus }^{\circledR} \\
\text { /TangoBlac } \\
\text { kPlus }\end{array}$ \\
\hline $\begin{array}{c}\text { Shore } \\
\text { hardness }\end{array}$ & -- & 20 (type 00) & $60-70$ (type 00) & $44-54$ (type A) & $\begin{array}{c}28-28 \\
\text { (type A) }\end{array}$ \\
\hline $\begin{array}{c}\text { Elastic } \\
\text { modulus } \\
\text { (kPa) }\end{array}$ & 49 & 60 & 49 & $1320-2970$ & $965-1051$ \\
\hline $\begin{array}{c}\text { Tensile } \\
\text { strength } \\
\text { (MPa) }\end{array}$ & $4-9$ & 1.1 & $0.3-0.5$ & $3.51-7.65$ & $0.8-1.5$ \\
\hline
\end{tabular}


Although a lot of advances have been achieved in mimicking soft living tissues, it is not still possible to manufacture soft surgical planning prototypes using a 3D printer. The hydrogels like PVA or PHY are not consistent enough after being printed. For example, it is not possible to achieve a high printing height or a lot of layers without stiffening. That is why, as has been seen before, most of the surgical planning prototypes using soft silicones or hydrogels are being manufactured by molding. Also, PVA and PHY need to undergo multiple number of thaw-freeze cycles ${ }^{36,133}$. Regarding agarose, they suffer from limited lifetime, in other words, they lose water due to evaporation of their water.

Nevertheless, in 2015, Lucas et al. ${ }^{78}$ manufactured a surgical planning prototype by material jetting. A Connex 500 machine by Stratasys was used to make the physical model of a 3-year-old male with stage 4 MYCN amplified, high-risk, neuroblastoma (NB). See Figure 11. The bones, vessels and other parts were built using a white rigid opaque epoxy photopolymer. A different, soft and translucent material was used for the tumor.

The other two cases in the study of Lucas et al. ${ }^{78}$ were: (1) a 5-year-old male with a stage $4 \mathrm{MYCN}$ amplified, high-risk, NB; and (2) a 11-year- old male with a primary mediastinal synovial sarcoma (SS).

(A)

(B)

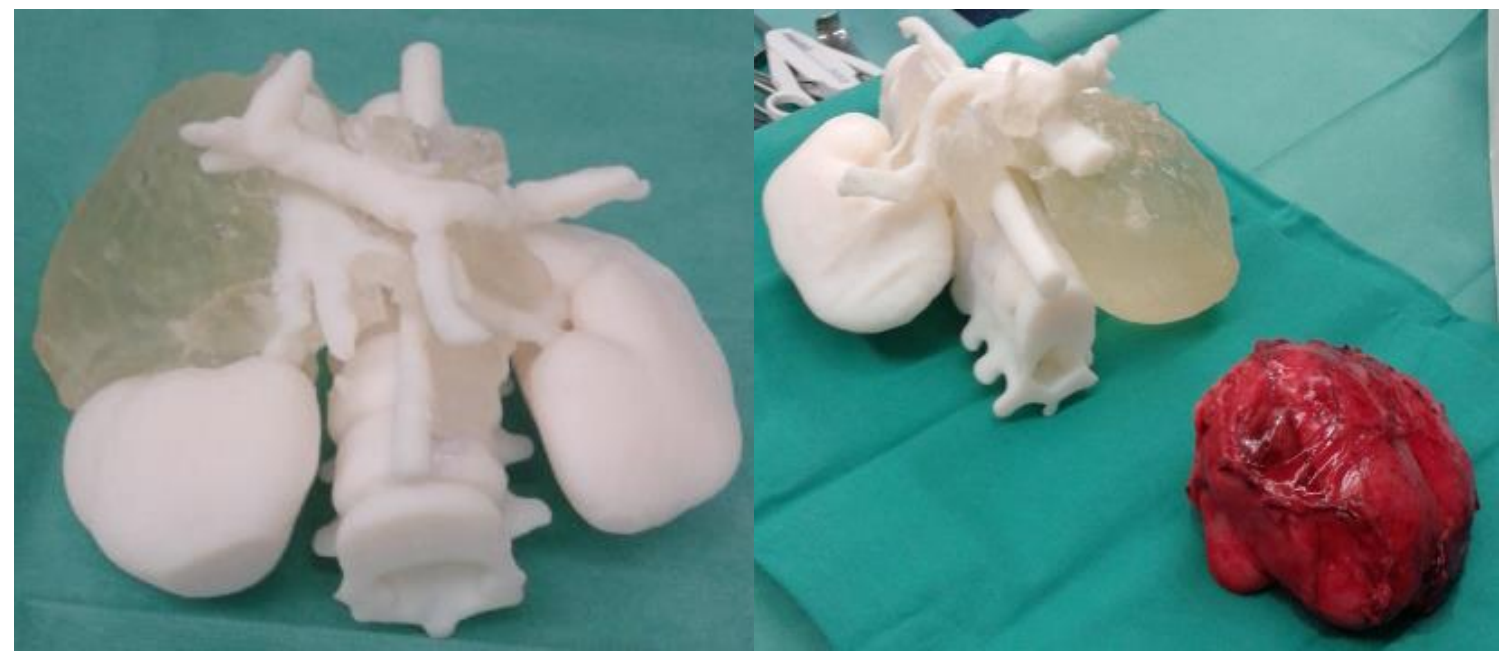

Figure 11. (A) 3D-printed prototype of a 3-year-old male with stage $4 \mathrm{MYCN}$ amplified, high-risk, neuroblastoma Tumor is represented in a semitransparent, "operable" consistency. (B) The tumor and surgical planning prototype tumor have the same size.

Continuing with material jetting, PolyJet ${ }^{\circledR} 3 \mathrm{D}$ printing technology of Stratasys is the most versatile 3D printing systems for manufacturing surgical planning prototypes for two reasons: (1) multi-color and (2) multi-material. As it was 
investigated in Zein et al. ${ }^{110}$, a surgical planning prototype for the preoperative planning was manufactured for preparing a liver transplant.

Although a lot of research has been carried out in this field, further in-depth analysis of other living tissues such as lungs, pancreas, etc., is necessary. Consequently, a complete table with many different parameters would be available and it would only be necessary to check which material best matches the desired organ.

\subsection{Patient Education}

Another important aspect in the preoperative planning surgery is the use of prototypes as a tool for patient education ${ }^{16}$, because they can be useful in order to improve the interaction between the doctors and patients. Previously, during the last years, the patients were shown different DICOM images. Now, with use of 3D physical models not only patients, but also their families, can know the nature of their illness better. Additionally, it will be easier for them to ask questions if they see a surgical planning prototype ${ }^{14}$.

This can be an important tool for communication with families, especially parents. Using these prototypes parents can understand what their children are suffering and see how the operation is going to proceed; they can discuss the operation with the surgeons ${ }^{17}$.

For instance, in Biglino et al. ${ }^{18} 20$ adolescent patients with an age range 15-18 years were assessed about the surgical planning prototypes manufactured for their cardiac models. In general, there was an improvement in confidence, knowledge, narrative and patient experience was improved in comparison with the lack of a 3D physical model.

Another example is that in Bernhard et al. ${ }^{16}$, where seven patients with a kidney tumor underwent a four-phase multi-detector computerized tomography (MDCT) scanning from which life-sized surgical planning prototypes were printed. As a result, they acquired a basic knowledge about the kidney's physiology and tumor characteristics, as well as the surgical procedure.

The use of 3D printed prototypes for patient education has some limitations. For example, in general, manufacturing 3D physical models is expensive ${ }^{25}$. Although in some studies like in Watson ${ }^{144}$, it was showed that the patient education can be low-cost as the surgical planning prototypes that were manufactured had a cost of less than $\$ 100$ per model. Another limitation is the mimicking characteristic. Nowadays, it is not possible to achieve a perfect matching between the materials and soft living tissues. Additionally, the best materials that can mimic soft living tissues (PVA, PHY, agarose) are mainly used by molding. 
Additionally, the design process is large, it takes a lot of time to manufacture a model ${ }^{81}$. Despite all these limitations, this field is starting to grow. 


\section{Process to obtain 3D Printed Surgical Planning Prototypes}

The process of 3D printing in medicine can vary depending on the aim of the application since some steps of this process may not be taken into account. Table 11 shows the steps to be carried out for each aim and AM technology (Table 11). The process of 3D printing explained below will be focused in surgical planning prototypes.

Table 11. Process for 3D printing in medicine of each technology and application.

\begin{tabular}{|c|c|c|c|c|c|c|c|c|c|c|c|}
\hline \multirow{3}{*}{$\begin{array}{c}\text { AM } \\
\text { Technologies } \\
\text { in Medicine }\end{array}$} & \multirow{3}{*}{ Aim } & \multirow{3}{*}{ Technology } & \multicolumn{2}{|c|}{ Pre-processing } & \multicolumn{4}{|c|}{ Processing } & \multicolumn{3}{|c|}{ Post-Processing (Application) } \\
\hline & & & \multirow{2}{*}{$\begin{array}{l}\text { Medical } \\
\text { Imaging }\end{array}$} & \multirow{2}{*}{$\begin{array}{l}\text { Design } \\
\text { Approach }\end{array}$} & \multirow{2}{*}{$\begin{array}{l}\text { Material } \\
\text { Selection }\end{array}$} & \multirow{2}{*}{$\begin{array}{c}\text { Cell } \\
\text { Selection }\end{array}$} & \multicolumn{2}{|c|}{ Printing } & \multirow{2}{*}{$\begin{array}{l}\text { Surgical } \\
\text { Planning } \\
\text { Prototypes }\end{array}$} & \multirow{2}{*}{$\begin{array}{c}\text { Tissue } \\
\text { Engineering }\end{array}$} & \multirow{2}{*}{ Implants } \\
\hline & & & & & & & Bioink & $\begin{array}{c}\text { No } \\
\text { Bioink }\end{array}$ & & & \\
\hline \multirow{6}{*}{ Use of Cells } & \multirow{3}{*}{$\begin{array}{l}\text { 3D Printing } \\
\text { Cells }\end{array}$} & InkJet & $\checkmark$ & $\checkmark$ & $\checkmark$ & $\checkmark$ & $\checkmark$ & & & $\checkmark$ & \\
\hline & & LAB & $\checkmark$ & $\checkmark$ & $\checkmark$ & $\checkmark$ & $\checkmark$ & & & $\checkmark$ & \\
\hline & & Robocasting/DIW & $\checkmark$ & $\checkmark$ & $\checkmark$ & $\checkmark$ & $\sqrt{ }$ & & & $\checkmark$ & \\
\hline & \multirow{3}{*}{$\begin{array}{l}\text { Scaffolds } \\
\text { for } \\
\text { Seeding } \\
\text { Cells }\end{array}$} & Robocasting/DIW & $\checkmark$ & $\checkmark$ & $\checkmark$ & $\checkmark$ & & $\checkmark$ & & $\checkmark$ & $\checkmark$ \\
\hline & & FFF & $\checkmark$ & $\checkmark$ & $\checkmark$ & $\checkmark$ & & $\checkmark$ & & $\checkmark$ & $\checkmark$ \\
\hline & & $\begin{array}{c}\text { Vat photo } \\
\text { polymerization }\end{array}$ & $\checkmark$ & $\checkmark$ & $\checkmark$ & $\checkmark$ & & $\checkmark$ & & $\checkmark$ & $\checkmark$ \\
\hline \multirow{4}{*}{$\begin{array}{l}\text { No Use of } \\
\text { Cells }\end{array}$} & \multirow{4}{*}{$\begin{array}{l}\text { Models for } \\
\text { Surgical } \\
\text { Planning }\end{array}$} & FFF & $\checkmark$ & $\checkmark$ & $\checkmark$ & & & $\checkmark$ & $\checkmark$ & & \\
\hline & & PBF Plastics & $\checkmark$ & $\checkmark$ & $\checkmark$ & & & $\checkmark$ & $\checkmark$ & & \\
\hline & & SLA & $\checkmark$ & $\checkmark$ & $\checkmark$ & & & $\checkmark$ & $\checkmark$ & & \\
\hline & & Material Jetting & $\checkmark$ & $\checkmark$ & $\checkmark$ & & & $\checkmark$ & $\checkmark$ & & \\
\hline
\end{tabular}




\begin{tabular}{|ccccccc|}
\hline $\begin{array}{c}\text { External } \\
\text { Parts }\end{array}$ & PBF Plastics & $\checkmark$ & $\checkmark$ & $\checkmark$ & $\checkmark$ \\
\cline { 2 - 7 } $\begin{array}{c}\text { Surgical } \\
\text { Guides }\end{array}$ & PBF Plastics & $\checkmark$ & $\checkmark$ & $\checkmark$ & $\checkmark$ & $\checkmark$ \\
\hline $\begin{array}{c}\text { Internal } \\
\text { Parts }\end{array}$ & PBF Plastics & $\checkmark$ & $\checkmark$ & $\checkmark$ & $\checkmark$ & $\checkmark$ \\
\hline
\end{tabular}




\subsection{Pre-processing}

Surgical planning prototypes need pre-processing before they are manufactured. This pre-processing includes the obtaining of medical images using CT (computer tomography) and MRI (magnetic resonance imaging), in DICOM (Digital Imaging and Communications in Medicine) format. These images are then segmented.

\subsubsection{Medical Imaging}

The first step is to provide information about the architecture, composition and organization of the corresponding tissue. Hence, medical imaging technology employs the most non-invasive imaging techniques such as CT (computer tomography) and MRI (magnetic resonance imaging), as they easily identify the different living tissues.

CT imaging is the method for obtaining multiple 2D X-ray images of the organ , which are then processed by computer so as to produce an image ${ }^{141}$. The amount of X-rays absorbed by each tissue depends on the physical density $\left(\mathrm{g} / \mathrm{cm}^{3}\right)$ or chemical composition (atomic number). In other words, the differences in absorption between bone, fat, air and water produce high contrast images of anatomical structures ${ }^{145}$ (Table 12).

Table 12. Physical characteristic of contrast-producing materials ${ }^{128}$.

\begin{tabular}{|c|c|c|}
\hline Material & $\begin{array}{l}\text { Effective Atomic Number } \\
\text { (Z) }\end{array}$ & Density $\left(\mathrm{g} / \mathrm{cm}^{3}\right)$ \\
\hline Water & 7.42 & 1 \\
\hline Muscle & 7.46 & $\overline{1}$ \\
\hline Fat & 5.92 & 0.91 \\
\hline Air & 7.64 & 0.00129 \\
\hline Calcium & 20 & 1.55 \\
\hline Iodine & 53 & 4.94 \\
\hline Barium & 56 & 3.5 \\
\hline
\end{tabular}

The maximum resolution is limited by what could be achieved at the start, with the acquisition of the images. It can be faced as it was presented in Arai et al. ${ }^{7}$ : the development of a computerized tomography device for dental use which generates images based on voxels of $136 \mu \mathrm{m}$ edge with a resolution of 398 elements per $\mathrm{mm}^{2}$. Also, it was stated in Winder et al. ${ }^{146}$ that the limit in the resolution is due to the image capture technology, not the rapid prototyping technology.

Fast evaluation ${ }^{83}$ is one of the most important advantages, since patients are treated as quickly as possible and hospitalization time is also reduced. This has 
a great impact on the cost savings. Also, it provides information about the components position ${ }^{101}$. However, the main drawbacks are radiation and an intravenous injection of iodine-containing contrast ${ }^{24}$, which becomes nephrotoxic. In addition, it is limited to examining the soft tissues ${ }^{113}$.

On the other hand, MRI uses nuclear magnetic resonance, a strong magnetic field that causes a very small fraction of the nuclei in targeted tissues of interest to align themselves with the magnetic field ${ }^{113}$. This technique increases the contrast resolution and it is therefore easier to differentiate soft tissues which are close to each other ${ }^{146}$; additionally, it does not use radiation ${ }^{120}$. However, it is an expensive technique, so accessibility is limited ${ }^{101}$.

The images obtained in both medical imaging technologies are saved in DICOM (Digital Imaging and Communications in Medicine) format. Its main purpose is to enable communication of diagnostic and therapeutic information, images and associated data of any kind ${ }^{13,94}$.

\subsubsection{Design Approach}

After the acquisition data in DICOM format, a process known as segmentation is carried out. This entails isolating the area of interest in order to make it easier to analyze ${ }^{106}$. By determining a threshold value for the area of interest ${ }^{140}$, the tissue anatomy can be captured. There are both open-source (3DSlicer, Cura) and proprietary-software programs (the best known, Materialise Mimics) for use with the DICOM.

When the segmentation has finished, a surface mesh is extracted, as the data from voxels (basic units of volumetric representation ${ }^{96}$ ) is converted into a mesh composed of a series of triangles ${ }^{92}$. Artifacts are found, but they can be eradicated manually or by automated algorithms ${ }^{131}$.

Finally, the data is saved in Standard Triangle Language (STL) file format, the most common 3D printer software. There are other types such as 3MF (3D Manufacturing Format) or AMF (Additive Manufacturing File Format).

$3 \mathrm{MF}$ is a relatively new file format developed by the 3MF consortium, in which various large and important companies are involved. AMF was introduced in 2011, as an alternative to STL and it has native support for color, materials, lattices and constellations ${ }^{91,138 .}$. 


\subsection{Processing}

In terms of surgical planning, this second step is focused on the material selection and then printing the 3D physical model. In some application the cell selection is necessary. For instance, bioprinting.

\subsubsection{Material Selection}

The central problem in the 3D printing field has been to find materials that are not only compatible with biological materials and the printing procedure, but can also offer the necessary mechanical and functional properties for tissue constructs. There is a huge number of materials that can be used, depending on the application, such as: polymers ${ }^{38}$, ceramics ${ }^{154}$ and metals ${ }^{15}$. In addition, it is worth noting that, depending on the material, one or another additive manufacturing process can be used.

Although a lot of materials can be used in medicine, natural polymers (alginate ${ }^{159}$, gelatin ${ }^{160}$, collagen ${ }^{157} \ldots$ ) or synthetic polymers (polyethylene glycol ${ }^{116}$ ) are the most commonly used. On the one hand, natural polymers offer high biocompatibility ${ }^{119}$ with the tissues, but poor mechanical properties ${ }^{8}$. On the other hand, synthetic polymers offer better mechanical properties compared with the natural polymers mentioned since they are manufactured with specific properties, but their biocompatibility is not so good ${ }^{99}$.

So, in general, taking into account all the ideas mentioned about the polymers, it is clear that the ideal biomaterial should include the following characteristics ${ }^{99}$ :

- Printability: the need to facilitate handling and deposition by the printer which may include viscosity, the method of crosslinking and rheological properties ${ }^{69}$.

- Mechanical properties: the biomaterial should match the mechanical properties of the organ.

- Biomimicry: the desired materials should be based on the knowledge of the tissue which they will mimic.

In terms of preoperative surgical planning, polymers are the only material that is used in this application: silicones, hydrogels (polyvinyl alcohol, Phytagel, polyamide), etc. Additionally, the material should only accomplish the three aforementioned characteristics: printability, mechanical properties and biomimicry.

\subsubsection{Cell Selection}

In preoperative surgical planning, the cell selection is skipped since surgical planning prototype does not require any cell. In other applications, like in Polonio- 
Alcalá et al. ${ }^{111}$, cells are selected and cultured in 3D printed PLA scaffolds for investigating triple-negative breast cancer.

\subsubsection{Printing}

This last step of the process might depend on the application. On the one hand, in terms of surgical planning, the materials chosen are 3D printed and the surgical planning prototype is manufactured.

On the other hand, if cells are required, bioinks will be used. Bioinks are bioprintable materials with living cells used in 3D bioprinting processes to manufacture living tissues and organs layer-by-layer 62 . 


\subsection{Post-processing}

\subsubsection{Application}

The use of surgical planning prototypes, which are 3D organ physical models, used by surgeons for practicing before the operation, ease the surgeons' work by giving them an idea of what they will face during surgery.

After the surgical planning prototypes have been finally manufactured, sometimes it is necessary to do a different post-processing. For example, if PVA filaments have been used as support, the prototype is immersed in water and the filaments are eliminated. In addition, as mentioned in some examples above, the parts printed in SLS need to be colored.

Finally, a validation is necessary in order to ensure the quality of the For that, there are two ways: (1) the validation of the doctors by checking the CT and MRI data obtained during the medical imaging step and comparing it with the real prototype or; (2) placing the prototype into a CT scanner ${ }^{2}$. 


\section{Ethical Issues}

When discussing additive manufacturing related to medical applications, there are several problems that can arise with respect to the ethical issues.

The development of additive manufacturing within medicine has brought a lot of improvements to the medical field: there is a lot of research focused on producing by AM an array of living tissues that should eliminate the need to use living or deceased human or animal transplants ${ }^{139}$. The creation of not only mimetic, but living, 3D-printed human parts could be applied both in preoperative surgical planning and in replacing damaged tissue or organs. Sooner or later even the creation of complete bodies will be possible. These advances will generate a lot of bioethical issues, related to a very relevant topic: "the death of death". This does not only refer to increasing lifespan with new AM parts: might it be possible for people to be re-born, by printing the complete body of a dead person? Now, with $\mathrm{AM}$, dead bodies can become just another reproducible object, like a commodity. These issues are, for the moment, very far removed from present medical/ethical problems such as the difficulties derived from cultural misconceptions when trying to convince family relatives about donating organs for transplantation.

Nevertheless, as the technology is being developed, it will be necessary to deal with it by applying new laws. For instance, the use of high-quality 3D printers should be limited to industry, hospitals and academia. Also, the DICOM images should only be available to doctors and patients (and on occasion to researchers for research purposes). Therefore, new laws and regulation must be made with regard to additive manufacturing surgical planning prototypes.

On the other hand, in order to avoid any issue, there are different laws that may have to be updated with respect to the new possibilities of the use of 3D printing for reproducing organs. As an example, nowadays not all types of tissues or cells could be used for 3D bioprinting or research purposes ${ }^{122}$. For instance, in Gilbert et al. ${ }^{52}$, it is questioned if any biological "ink" with embryonic stem cells should be allowed to be printed.

All in all, laws will need to encompass all the applications in which AM takes part for the correct use of this technology in the future. By this way, AM is being added to the ethical issues of the medical field.

\section{Future Perspective}

Regarding the future perspective, apart from the necessity of applying and regulating new rules and laws about the use of AM in certain fields (explained in Section 5); there is still a lot of research to do in other scientific areas. For 
example, nozzle clogging issues, more complex 3D structures, multi-materials 3D printing, 4D printing, etc.

Regarding nozzle clogging issues ${ }^{38}$ (a problem related to FFF and DIW AM technologies), it is extremely important to look for the optimal parameters for the printing precursor, in other words, the materials used. For instance, having proper viscosity (as stated previously, each method has its own viscosity parameters). The materials should also be homogeneous, as well as providing shear thinning properties. All of this should be achieved in order to create stable structures for use in the medical field.

Then, as each improvement in additive manufacturing is implemented, more and more advances will be required. Therefore, further in-depth research must be carried out to fulfil the future requirements. For example, mimicking perfectly the properties of living tissues. It is known that organs are complex structures since each tissue has its own specifications. Therefore, research is needed into the different materials which could match those features. Until now, some research 36,48,85,133 has been done with PVA, known as Poly (vinyl alcohol), and PHY (Phytagel).

Therefore, multi-material 3D printing is a future application that should be taken into account for mimicking the living tissues $77,78,117$. Better properties could be achieved by combining materials for some applications, which could also lead to obtaining better results in mimicking anisotropic living tissues ${ }^{72}$. So, depending on the layer, it is necessary to have either a composition of materials in greater or lesser proportion, or just one material. On the other hand, voxels will provide the opportunity to bring reality to 3D-printed multi-material objects, in this case living tissues, based on MRI files ${ }^{158}$. Hybrid multi-material 3D printers will be a way to manufacture multi-material surgical planning prototypes. For example, in a hybrid multi-material 3D printer, two technologies such as FFF and DIW could be joined. On the one hand, FFF would be used for thermoplastic filaments such as PLA, whereas DIW would be used liquids (mainly silicones and hydrogels).

And last but not least, 4D printing is starting to bloom. It involves printing multimaterial samples that have the capability to transform over time ${ }^{136}$. It could be extremely useful for developing different materials which could mimic the living tissue even after transplantation, since the body is in continuously changing 87,123 . An example of this is the modification in the morphology of the organs, and consequently, in the properties of the living tissue. So, it is important to fulfil the requirement over a long period of time, not only during the transplantation. It must be emphasized that if an organ is transplanted during the childhood, it is obvious that the materials used for mimicking that tissue need to adapt to these changes.

\section{Conclusions}


In light of the above, additive manufacturing is generating many changes in the medical field. Therefore, it is possible to deal with many typical in medicine, such as the lack of medical training for surgeons and knowledge of patients. Different AM techniques can be used depending on the parameters of the materials and the desired application.

Before printing the desired piece, it is necessary to follow the process which starts with the acquisition of CT and MRI images in DICOM format, as well as the posterior design approach using different software to obtain a STL file. It is also important to take into account the properties of the materials which could be used.

As stated above, the surgical planning prototypes are an excellent way to apply this process. They give the surgeons the chance to practice before the operation, prepare them for the reality of the operation. However, until now, most of the prototypes could not achieve a good mimicking due to the limitations of the materials: bad printing properties, high hardness, etc.

They also enable future doctors training in Medical School to have a better idea of the human body. Additionally, these 3D physical models are used by the doctors for patient education. They show the 3D models to both families and patients before the operation. In addition, the knowledge of patients and families improves after seeing the model.

It is clear that these advances will be helpful for society, since the quality of life will improve. For example, life expectancy will increase; there will be fewer illnesses or faster healing and regeneration, etc. Nonetheless, all of this could engender some the ethical issues must be taken into account.

\section{Conflict of interest}

The authors declare that they have no conflict of interest.

\section{References}

1. Abouna, G. M. Organ Shortage Crisis: Problems and Possible Solutions. Transplant. Proc. 40:34-38, 2008.

2. Adams, F., T. Qiu, A. Mark, B. Fritz, L. Kramer, D. Schlager, U. Wetterauer, A. Miernik, and P. Fischer. Soft 3D-Printed Phantom of the Human Kidney with Collecting System. Ann. Biomed. Eng. 45:963-972, 2017.

3. Agarwal, A., N. Borley, and G. McLatchie. Oxford Handbook of Operative Surgery. 2017.

4. Akhtar, M. F., M. Hanif, and N. M. Ranjha. Methods of synthesis of hydrogels ... A review. Saudi Pharm. J. 24:554-559, 2016. 
5. Anderson, J. R., W. L. Thompson, A. K. Alkattan, O. Diaz, R. Klucznik, Y. J. Zhang, G. W. Britz, R. G. Grossman, and C. Karmonik. Three-dimensional printing of anatomically accurate, patient specific intracranial aneurysm models. J. Neurointerv. Surg. 8:517-520, 2016.

6. Andre, J. C., A. Le Mehaute, and O. De Witte. Dispositif pour realiser un module de piece industrielle. , 1984.at $<$ http://bases-brevets.inpi.fr/fr/document/FR2567668/publications.html>

7. Arai, Y., E. Tammisalo, K. Iwai, K. Hashimoto, and K. Shinoda. Development of a Compact Computed Tomographic Apparatus for Dental Use. Dentomaxillofacial Radiol. 28:245-248, 1999.

8. Ashby, M. F., L. J. Gibson, U. Wegst, and R. Olive. The mechanical properties of natural materials. Proc. $R$. Soc. Lond. A 450:123-140, 1995.

9. $\quad$ ASTM. D2240 Rubber Property—Durometer Hardness. 1-13, 2015.doi:10.1520/D2240-15.2

10. Attaran, M. The rise of 3-D printing: The advantages of additive manufacturing over traditional manufacturing Bus. Horiz. 60:677-688, 2017.

11. Azari, A., and S. Nikzad. The evolution of rapid prototyping in dentistry: A review. Rapid Prototyp. J. 15:216225, 2009.

12. Banks, D. P., C. Grivas, J. D. Mills, R. W. Eason, and I. Zergioti. Nanodroplets deposited in microarrays by femtosecond Ti:sapphire laser-induced forward transfer. Appl. Phys. Lett. 89:10-12, 2006.

13. Barghout, L., and L. Lee. U.S. Patent No. 10/618.543. , 2004.

14. van de Belt, T. H., H. Nijmeijer, D. Grim, L. J. L. P. G. Engelen, R. Vreeken, M. M. H. J. van Gelder, and M. ter Laan. Patient-Specific Actual-Size Three-Dimensional Printed Models for Patient Education in Glioma Treatment: First Experiences. World Neurosurg. 117:e99-e105, 2018.

15. Berman, B. 3-D printing: The new industrial revolution. Bus. Horiz. 55:155-162, 2012.

16. Bernhard, J. C., S. Isotani, T. Matsugasumi, V. Duddalwar, A. J. Hung, E. Suer, E. Baco, R. Satkunasivam, H Djaladat, C. Metcalfe, B. Hu, K. Wong, D. Park, M. Nguyen, D. Hwang, S. T. Bazargani, A. L. de Castro Abreu, M. Aron, O. Ukimura, and I. S. Gill. Personalized 3D printed model of kidney and tumor anatomy: a useful tool for patient education. World J. Urol. 34:337-345, 2016.

17. Biglino, G., C. Capelli, J. Wray, S. Schievano, L. K. Leaver, S. Khambadkone, A. Giardini, G. Derrick, A. Jones, and A. M. Taylor. 3D-manufactured patient-specific models of congenital heart defects for communication in clinical practice: feasibility and acceptability. BMJ Open 5:e007165, 2015.

18. Biglino, G., D. Koniordou, M. Gasparini, C. Capelli, L. K. Leaver, S. Khambadkone, S. Schievano, A. M. Taylor, and J. Wray. Piloting the Use of Patient-Specific Cardiac Models as a Novel Tool to Facilitate Communication During Cinical Consultations. Pediatr. Cardiol. 38:813-818, 2017.

19. Billiet, T., M. Vandenhaute, J. Schelfhout, S. Van Vlierberghe, and P. Dubruel. A review of trends and limitations in hydrogel-rapid prototyping for tissue engineering. Biomaterials 33:6020-6041, 2012.

20. Bohandy, J., B. F. Kim, and F. J. Adrian. Metal deposition from a supported metal film using an excimer laser. J. Appl. Phys. 60:1538-1539, 1986.

21. Bose, S., S. Vahabzadeh, and A. Bandyopadhyay. Bone tissue engineering using 3D printing. Mater. Today 16:496-504, 2013

22. Buj-Corral, I., A. Bagheri, and O. Petit-Rojo. 3D printing of porous scaffolds with controlled porosity and pore size values. Materials (Basel). 11:1-18, 2018

23. Chang, R., J. Nam, and W. Sun. Effects of Dispensing Pressure and Nozzle Diameter on Cell Survival from Solid Freeform Fabrication-Based Direct Cell Writing. Tissue Eng. Part A 14:41-48, 2008.

24. Chelu, R. G., D. van der Linder, and K. Nieman. Cardiovascular Imaging in Aneurysm-Osteoarthritis Syndrome. Aneurysms-Osteoarthritis Syndr. 5:103-114, 2017.

25. Chen, Z., Z. Li, J. Li, C. Liu, C. Lao, Y. Fu, C. Liu, Y. Li, P. Wang, and Y. He. 3D printing of ceramics: A review. J. Eur. Ceram. Soc. 39:661-687, 2019.

26. Chikwe, J., A. C. de Souza, and J. R. Pepper. No time to train the surgeons. 2004.

27. Chockalingam, K., N. Jawahar, U. Chandrasekar, and K. N. Ramanathan. Establishment of process model for part strength in stereolithography. J. Mater. Process. Technol. 208:348-365, 2008.

28. Christensen, A. M., S. M. Humphries, K. Y. C. Goh, and D. Swift. Advanced "tactile" medical imaging for separation surgeries of conjoined twins. Child's Nerv. Syst. 20:547-553, 2004. 
29. de Ciurana, Q., Á. Fernández, and M. Monzón. Guía de tecnologías de rapid manufacturing. 2006.

30. Colton, J., B. Blair, and B. Blair. Experimental study of post-build cure of stereolithography polymers for injection. 1-8, 2006.

31. Comb, J. FDM technology process improvements. Proc. Solid ... 42-49, 1994.at <http://www.dtic.mil/cgibin/GetTRDoc?AD=ADA290949\#page=49>

32. Cosma, C., U. T. Cluj-napoca, C. Moldovan, U. T. Cluj-napoca, R. I. Campbell, and A. Cosma. Theoretical Analysis and Practical Case Studies of Powder- Powder-Based Additive Manufacturing. 61:401-408, 2018.

33. Crump, S. S. U.S. Patent No. 5,121,329. , 1992.

34. Cui, X., T. Boland, D. DD'Lima, and M. K Lotz. Thermal inkjet printing in tissue engineering and regenerative medicine. Recent Pat. Drug Deliv. Formul. 6:149-155, 2012.

35. Dababneh, A. B., and I. T. Ozbolat. Bioprinting Technology: A Current State-of-the-Art Review. J. Manuf. Sci. Eng. 136:061016, 2014.

36. Dankelman, J., J. J. van den Dobbelsteen, L. H. Pluymen, T. L. de Jong, D. J. van Gerwen, and G.-J. Kleinrensink. PVA matches human liver in needle-tissue interaction. J. Mech. Behav. Biomed. Mater. 69:223228, 2017.

37. Deckard, C. R. U.S. Patent No. 4,863,538. , 1989.

38. Derakhshanfar, S., R. Mbeleck, K. Xu, X. Zhang, W. Zhong, and M. Xing. 3D bioprinting for biomedical devices and tissue engineering: A review of recent trends and advances. Bioact. Mater. 3:144-156, 2018.

39. Duan, B., L. A. Hockaday, K. H. Kang, and J. T. Butcher. 3D bioprinting of heterogeneous aortic valve conduits with alginate/gelatin hydrogels. J. Biomed. Mater. Res. Part A 101:1255-1264, 2013.

40. Duan, B., M. Wang, W. Y. Zhou, W. L. Cheung, Z. Y. Li, and W. W. Lu. Three-dimensional nanocomposite scaffolds fabricated via selective laser sintering for bone tissue engineering. Acta Biomater. 6:4495-4505, 2010.

41. Ellis, A., L. Hartley, and N. Hopkinson. Effect of Print Density on the Properties of High Speed Sintered Elastomers. Metall. Mater. Trans. A Phys. Metall. Mater. Sci. 46:3883-3886, 2015.

42. Esteves, R., R. Esteves, N. Onukwuba, and B. Dikici. Determination of Surfactant Solution Viscosities with a Rotational Viscometer Determination of Surfactant Solution Viscosities with a Rotational Viscometer. 1:, 2016.

43. Faroogi, K. M., O. Saeed, A. Zaidi, J. Sanz, J. C. Nielsen, D. T. Hsu, and U. P. Jorde. 3D Printing to Guide Ventricular Assist Device Placement in Adults With Congenital Heart Disease and Heart Failure. JACC Hear. Fail. 4:301-311, 2016.

44. Fenollosa, F. Contribució a l'estudi de la impressió 3D per a la fabricació de models per facilitar l'assaig d'operacions quirúrgiques de tumors. , 2019.

45. Ferry, M. P. W., J. Feijen, and D. Grijpma. A review on stereolithography and its applications in biomedica engineering. Biomaterials 31:6121-6130, 2010.

46. Feuerhahn, F., A. Schulz, T. Seefeld, and F. Vollertsen. Microstructure and properties of selective laser melted high hardness tool steel. Phys. Procedia 41:843-848, 2013.

47. Flanagan, C. L., S. J. Hollister, R. M. Schek, S. E. Feinberg, S. Das, J. M. Williams, P. H. Krebsbach, and A Adewunmi. Bone tissue engineering using polycaprolactone scaffolds fabricated via selective laser sintering. Biomaterials 26:4817-4827, 2005 .

48. Forte, A. E., S. Galvan, F. Manieri, F. Rodriguez y Baena, and D. Dini. A composite hydrogel for brain tissue phantoms. Mater. Des. 112:227-238, 2016.

49. Franta, I. Elastomers and Rubber Compounding Materials. 1989, 607 pp.

50. Gauvin, R., Y. C. Chen, J. W. Lee, P. Soman, P. Zorlutuna, J. W. Nichol, and A. Khademhosseini. Microfabrication of complex porous tissue engineering scaffolds using 3D projection stereolithography. Biomaterials 33:3824-3834, 2012.

51. Gibson, I., D. Rosen, and B. Stucker. Generalized Additive Manufacturing Process Chain. In: Additive Manufacturing Technologies. 2014, pp. 43-61.

52. Gilbert, F., C. D. O'Connell, T. Mladenovska, and S. Dodds. Print Me an Organ? Ethical and Regulatory Issues Emerging from 3D Bioprinting in Medicine. Sci. Eng. Ethics 24:73-91, 2018.

53. Gobin, A. S., R. H. Schmedlen, A. T. Tsai, J. L. West, and B. K. Mann. Smooth muscle cell growth in 
photopolymerized hydrogels with cell adhesive and proteolytically degradable domains: synthetic ECM analogs for tissue engineering. Biomaterials 22:3045-3051, 2002.

54. Gokuldoss, P. K., S. Kolla, and J. Eckert. Additive manufacturing processes: Selective laser melting, electron beam melting and binder jetting-selection guidelines. Materials (Basel). 10:, 2017.

55. Gross, B. C., J. L. Erkal, S. Y. Lockwood, C. Chen, and D. M. Spence. Evaluation of 3D printing and its potential impact on biotechnology and the chemical sciences. , 2014.

56. Guillotin, B., S. Catros, and F. Guillemot. Laser assisted bio-printing (LAB) of cells and bio-materials based on laser induced forward transfer (LIFT). Laser Technol. Biomimetics 193-209, 2013.

57. Guillotin, B., A. Souquet, S. Catros, M. Duocastella, B. Pippenger, S. Bellance, R. Bareille, M. Rémy, L. Bordenave, J. Amédée j, and F. Guillemot. Laser assisted bioprinting of engineered tissue with high cell density and microscale organization. Biomaterials 31:7250-7256, 2010.

58. Harsha Vardhan, G., G. H. Charan, P. V. S. Reddy, and K. Sampath Kumar. International Journal on Recent and Innovation Trends in Computing and Communication 3D Printing: The Dawn of a New Era in Manufacturing. 2373-2376, 2014.at <http://www.ijritcc.org>

59. Ho, H. C. H., I. Gibson, and W. L. Cheung. Effects of energy density on morphology and properties of selective laser sintered polycarbonate. J. Mater. Process. Technol. 89-90:204-210, 1999.

60. Hocheng, H., H. Y. Tsai, U. U. Jadhav, K. Y. Wang, and T. C. Lin. Laser Surface Patterning. Mater. Sci. Mater. Eng. 9:75-113, 2014

61. Homma, T., N. Kunito, and S. Kamado. Fabrication of extraordinary high-strength magnesium alloy by hot extrusion. Scr. Mater. 61:644-647, 2009.

62. Hospodiuk, M., M. Dey, D. Sosnoski, and I. T. Ozbolat. The bioink: A comprehensive review on bioprintable materials. Biotechnol. Adv. 35:217-239, 2017.

63. Hull, C. On stereolithography. Virtual Phys. Prototyp. 27:177-177, 2012.

64. Hull, C. W. U.S. Patent No. 4.575.330. , 1986.

65. Igami, T., Y. Nakamura, T. Hirose, T. Ebata, Y. Yokoyama, G. Sugawara, T. Mizuno, K. Mori, and M. Nagino. Application of a three-dimensional print of a liver in hepatectomy for small tumors invisible by intraoperative ultrasonography: Preliminary experience. World J. Surg. 38:3163-3166, 2014.

66. Irvine, S. A., and S. S. Venkatraman. Bioprinting and differentiation of stem cells. Molecules 21:, 2016.

67. Ito, K., K. Furuya, Y. Okano, and L. Hamada. Development and characteristics of a biological tissue-equivalent phantom for microwaves. Electron. Commun. Japan (Part I Commun. 84:67-77, 2001.

68. James, W. J., M. A. Slabbekoorn, W. A. Edgin, and C. K. Hardin. Correction of congenital malar hypoplasia using stereolithography for presurgical planning. J. oral Maxillofac. Surg. 56:512-517, 1998.

69. Jammalamadaka, U., and K. Tappa. Recent advances in biomaterials for 3D printing and tissue engineering. J. Funct. Biomater. 9:, 2018.

70. Jardini, A. L., M. A. Larosa, C. A. de Carvalho Zavaglia, L. F. Bernardes, C. S. Lambert, P. Kharmandayan, D. Calderoni, and R. Maciel Filho. Customised titanium implant fabricated in additive manufacturing for craniomaxillofacial surgery: This paper discusses the design and fabrication of a metallic implant for the reconstruction of a large cranial defect. Virtual Phys. Prototyp. 9:115-125, 2014.

71. Kappanayil, M., N. Rao Koneti, R. R Kannan, B. P Kottayil, and K. Kumar. Three-dimensional-printed cardiac prototypes aid surgical decision-making and preoperative planning in selected cases of complex congenital heart diseases: Early experience and proof of concept in a resource-limited environment. Ann. Pediatr. Cardiol. $0: 117-125,2017$.

72. Kassab, G. S., and M. S. Sacks. Structure-based mechanics of tissues and organs. 2016.

73. Kempen, K., L. Thijs, J. Van Humbeeck, and J. P. Kruth. Mechanical Properties of AISi10Mg Produced by Selective Laser Melting. Phys. Procedia 39:439-446, 2012.

74. Kim, K., A. Yeatts, D. Dean, and J. P. Fisher. Stereolithographic Bone Scaffold Design Parameters: Osteogenic Differentiation and Signal Expression. Tissue Eng. Part B Rev. 16:523-539, 2010.

75. Kirchmajer, D. M., and R. Gorki lii. An overview of the suitability of hydrogel-forming polymers for extrusionbased 3D-printing. J. Mater. Chesmitry 3:4105-4117, 2015.

76. Kodama, H. Automatic method for fabricating a three-dimensional plastic model with photo-hardening polymer Rev. Sci. Instrum. 60:677-688, 1981. 
77. Kokkinis, D., M. Schaffner, and A. R. Studart. Multimaterial magnetically assisted 3D printing of composite materials. Nat. Commun. 6:, 2015.

78. Krauel, L., F. Fenollosa, L. Riaza, M. Pérez, X. Tarrado, A. Morales, J. Gomà, and J. Mora. Use of 3D Prototypes for Complex Surgical Oncologic Cases. World J. Surg. 40:889-894, 2016.

79. Kresz, N., Z. Bor, T. Smausz, D. B. Chrisey, N. Barna, A. Szabó, L. Kolozsvári, B. Hopp, and A. Nógrádi. Survival and Proliferative Ability of Various Living Cell Types after Laser-Induced Forward Transfer. Tissue Eng. 11:1817-1823, 2006.

80. Kruth, J. P., L. Froyen, J. Van Vaerenbergh, P. Mercelis, M. Rombouts, and B. Lauwers. Selective laser melting of iron-based powder. J. Mater. Process. Technol. 149:616-622, 2004.

81. Kurenov, S. N., C. Ionita, D. Sammons, and T. L. Demmy. Three-dimensional printing to facilitate anatomic study, device development, simulation, and planning in thoracic surgery. J. Thorac. Cardiovasc. Surg. 149:973-979.e1, 2015.

82. Kusaka, M., M. Sugimoto, N. Fukami, H. Sasaki, M. Takenaka, T. Anraku, T. Ito, T. Kenmochi, R. Shiroki, and K. Hoshinaga. Initial experience with a tailor-made simulation and navigation program using a 3-D printer model of kidney transplantation surgery. Transplant. Proc. 47:596-599, 2015.

83. Lars, G. W., L. Whal, and Y. Shi-Joon. Magnetic resonance imaging and computer tomography. Paediatr. Cardiol. (Third Ed. 18:363-378, 2010.

84. Leary, M., M. Mazur, J. Elambasseril, M. McMillan, T. Chirent, Y. Sun, M. Qian, M. Easton, and M. Brandt. Selective laser melting (SLM) of AISi12Mg lattice structures. Mater. Des. 98:344-357, 2016.

85. Leibinger, A., A. E. Forte, Z. Tan, M. J. Oldfield, F. Beyrau, D. Dini, and F. Rodriguez y Baena. Soft Tissue Phantoms for Realistic Needle Insertion: A Comparative Study. Ann. Biomed. Eng. 44:2442-2452, 2016.

86. Leong, K. F., S. S. Venkatraman, C. K. Chua, N. Sudarmadji, Y. C. F. Boey, H. Y. Yu, L. P. Tan, and W. Y Yeong. Porous polycaprolactone scaffold for cardiac tissue engineering fabricated by selective laser sintering. Acta Biomater. 6:2028-2034, 2009.

87. Lewis, J. A., R. G. Nuzzo, L. Mahadevan, A. Sydney Gladman, and E. A. Matsumoto. Biomimetic 4D printing. Nat. Mater. 15:413-418, 2016.

88. Liao, C. Y., W. J. Wu, C. T. Hsieh, H. C. Yang, C. S. Tseng, and S. hui Hsu. Water/ice as sprayable sacrificial materials in low-temperature 3D printing for biomedical applications. Mater. Des. 160:624-635, 2018.

89. Linares-Alvelais, J. A. R., J. Obedt Figueroa-Cavazos, C. Chuck-Hernandez, H. R. Siller, C. A. Rodríguez, and J. I. Martínez-López. Hydrostatic high-pressure post-processing of specimens fabricated by DLP, SLA, and FDM: An alternative for the sterilization of polymer-based biomedical devices. Materials (Basel). 11:, 2018.

90. Maeda, K., and T. H. C. Childs. Laser sintering (SLS) of hard metal powders for abrasion resistant coatings. J. Mater. Process. Technol. 149:609-615, 2004.

91. Manufacturing, A., and F. Format. INTERNATIONAL STANDARD ISO / ASTM Specification for Additive Manufacturing File Format ( AMF ). 2016:, 2016.

92. Marro, A., T. Bandukwala, and W. Mak. Three-Dimensional Printing and Medical Imaging: A Review of the Methods and Applications. Curr. Probl. Diagn. Radiol. 45:2-9, 2016.

93. Mehrali, M., H. S. C. Metselaar, H. Yarmand, N. A. A. Osman, N. Adib Kadri, S. Gharehkhani, and S. F. S. Shirazi. A review on powder-based additive manufacturing for tissue engineering: selective laser sintering and inkjet 3D printing. Sci. Technol. Adv. Mater. 16:033502, 2015.

94. Mildenberger, P., M. Eichelberg, and E. Martin. Introduction to the DICOM standard. Eur. Radiol. 12:920-927, 2002.

95. Mohebi, M. M., and J. R. Evans. A drop-on-demand ink-jet printer for combinatorial libraries and functionally graded ceramics. J. Comb. Chem. 4:267-274, 2002.

96. Morvan, S. M. Heterogeneous solids: possible representation schemes. Proc. Solid Free. 187-198, 1999.at <http://utwired.utexas.edu/lff/symposium/proceedingsArchive/pubs/Manuscripts/1999/1999-022-Morvan.pdf>

97. Mueller, J., K. Shea, and C. Daraio. Mechanical properties of parts fabricated with inkjet 3D printing through efficient experimental design. Mater. Des. 86:902-912, 2015.

98. Muguruza Blanco, A., L. Krauel, and F. Fenollosa Artés. Development of a patients-specific 3D-printed preoperative planning and training tool, with functionalized internal surfaces, for complex oncologic cases. Rapid Prototyp. J. 25:363-377, 2019.

99. Murphy, S. V., and A. Atala. 3D bioprinting of tissues and organs. Nat. Biotechnol. 32:773-785, 2014. 
100. Naahidi, S., M. Jafari, M. Logan, Y. Wang, Y. Yuan, H. Bae, and P. Chen. Biocompatibility of hydrogel-based scaffolds for tissue engineering applications. Biotechnol. Adv. 35:530-544, 2017.

101. Nam, D., R. L. Barrack, and H. G. Potter. What Are the Advantages and Disadvantages of Imaging Modalities to Diagnose Wear-related Corrosion Problems? Clin. Orthop. Relat. Res. 472:3665-3673, 2014.

102. Nizam, A., G. R., N. N.L., H. A.B., and S. A.R. Dimensional Accuracy of the Skull Models Produced by Rapid Prototyping Technology Using Stereolithography Apparatus. Arch. Orofac. Sci. 1:60-66, 2006.

103. Nizar N. Zein, Ibrahim A. Hanouneh, Paul D. Bishop, Maggie Samaan, B. E., and R. K. Cristiano Quintini, Charles Miller, Lisa Yerian. Three-Dimensional Print of a Liver for Preoperative Planning in Living Donor Liver Transplantation. Liver Transplant. 19:1304-1310, 2013.

104. Noor, N., A. Shapira, R. Edri, I. Gal, L. Wertheim, and T. Dvir. 3D Printing of Personalized Thick and Perfusable Cardiac Patches and Hearts. Adv. Sci. 6:, 2019.

105. Nune, K. C., S. Li, and R. D. K. Misra. Advancements in three-dimensional titanium alloy mesh scaffolds fabricated by electron beam melting for biomedical devices: mechanical and biological aspects. Sci. China Mater. 61:1-20, 2017.

106. Ovsianikov, A., S. Lin, K. Hölzl, L. Tytgat, S. Van Vlierberghe, and L. Gu. Bioink properties before, during and after 3D bioprinting. Biofabrication 8:032002, 2016.

107. Oyen, M. L. Mechanical characterisation of hydrogel materials. Int. Mater. Rev. 59:44-59, 2014.

108. Ozbolat, I. T., and M. Hospodiuk. Current advances and future perspectives in extrusion-based bioprinting. Biomaterials 76:321-343, 2016.

109. Ozbolat, I. T., and Y. Yu. Bioprinting toward organ fabrication: challenges and future trends. IEEE Trans Biomed Eng 60:691-699, 2013.

110. Perkins, J. D. Techniques to ensure adequate portal flow in the presence of splenorenal shunts. Liver Transplant. 13:767-768, 2007.

111. Polonio-Alcalá, E., M. Rabionet, X. Gallardo, D. Angelats, J. Ciurana, S. Ruiz-Martínez, and T. Puig. PLA electrospun scaffolds for three-dimensional triple-negative breast cancer cell culture. Polymers (Basel). 11:, 2019.

112. Polonio-Alcalá, E., M. Rabionet, A. J. Guerra, M. Yeste, J. Ciurana, and T. Puig. Screening of additive manufactured scaffolds designs for triple negative breast cancer 3D cell culture and stem-like expansion. Int. J. Mol. Sci. 19:, 2018

113. Pykett, I. L., H. Newhouse, J. Brady, R. Goldman, J. Philip, and M. Pohost. MAGNETIC RESONANCE of Nuclear. 157-168, 1982

114. Qi, L., J. C. Kash, V. G. Dugan, B. W. Jagger, Y. Lau, E. C. Crouch, K. L. Hartshorn, and J. K. Taubenberger. Application of Visible Light-based Projection Stereolithography for Live Cell-Scaffold Fabrication with Designed Architecture. Biomaterials 34:331-339, 2013.

115. Remmers, R., D. Cook, and V. Gervasi. Custom, Integrated, Pneumatic, Rotary Actuator for and Active AnkleFoot Orthosis. Solid Free. Fabr. Symp. 816-827, 2010.at

<http://sffsymposium.engr.utexas.edu/Manuscripts/2010/2010-69-Remers.pdf>

116. Rimann, M., E. Bono, H. Annaheim, M. Bleisch, and U. Graf-Hausner. Standardized 3D bioprinting of soft tissue models with human primary cells. J. Lab. Autom. 21:496-509, 2016.

117. Rutz, A. L., K. E. Hyland, A. E. Jakus, W. R. Burghardt, and R. N. Shah. A multimaterial bioink method for 3D printing tunable, cell-compatible hydrogels. Adv. Mater. 27:1607-1614, 2015.

118. Sekhar, A., M. R. Sun, and B. Siewert. A tissue phantom model for training residents in ultrasound-guided liver biopsy. Acad. Radiol. 21:902-908, 2014.

119. Selvamurugan, N., K. Ramasamy, A. Moorthi, M. Swetha, N. Srinivasan, and K. Sahithi. Biocomposites containing natural polymers and hydroxyapatite for bone tissue engineering. Int. J. Biol. Macromol. 47:1-4, 2010.

120. Semelka, R. C., D. M. Armao, J. Elias, and W. Huda. Imaging strategies to reduce the risk of radiation in CT studies, including selective substitution with MRI. J. Magn. Reson. Imaging 25:900-909, 2007.

121. Shaheen, E., A. Alhelwani, E. Van De Casteele, C. Politis, and R. Jacobs. Evaluation of Dimensional Changes of 3D Printed Models After Sterilization: A Pilot Study. Open Dent. J. 12:72-79, 2018. 
123. Shestopaloff, Y. K., and I. F. Sbalzarini. A method for modeling growth of organs and transplants based on the general growth law: Application to the liver in dogs and humans. PLoS One 9:, 2014.

124. Shiraishi, I., M. Yamagishi, K. Hamaoka, M. Fukuzawa, and T. Yagihara. Simulative operation on congenital heart disease using rubber-like urethane stereolithographic biomodels based on 3D datasets of multislice computed tomography. Eur. J. Cardio-thoracic Surg. 37:302-306, 2010.

125. Simpkins, M. W., R. L. Stewart, R. L. Parkhill, A. L. Stone, A. M. Kachurin, S. K. Williams, C. M. Smith, and W. L. Warren. Three-Dimensional BioAssembly Tool for Generating Viable Tissue-Engineered Constructs. Tissue Eng. 10:1566-1576, 2004.

126. Singh, D., and D. Thomas. Advances in medical polymer technology towards the panacea of complex 3D tissue and organ manufacture. Am. J. Surg. 217:807-808, 2018.

127. Smith, R. J., M. Hirsch, R. Patel, W. Li, A. T. Clare, and S. D. Sharples. Spatially resolved acoustic spectroscopy for selective laser melting. J. Mater. Process. Technol. 236:93-102, 2016.

128. Sprawls, P. Physical Principles of Medical Imaging Online. 1985.

129. Sugiyama, T., S. Lama, L. S. Gan, Y. Maddahi, K. Zareinia, and G. R. Sutherland. Forces of tool-tissue interaction to assess surgical skill level. JAMA Surg. 153:234-242, 2018.

130. Takahashi, K., and S. Yamanaka. Induction of Pluripotent Stem Cells from Mouse Embryonic and Adult Fibroblast Cultures by Defined Factors. Cell 126:663-676, 2006.

131. Tam, M. D., S. D. Laycock, D. G. Bell, and A. Chojnowski. 3-D printout of a DICOM file to aid surgical planning in a 6 year old patient with a large scapular osteochondroma complicating congenital diaphyseal aclasia. $J$. Radiol. Case Rep. 6:31-37, 2012.

132. Tan, C., K. Zhou, W. Ma, B. Attard, P. Zhang, and T. Kuang. Selective laser melting of high-performance pure tungsten: parameter design, densification behavior and mechanical properties. Sci. Technol. Adv. Mater. 19:370-380, 2018.

133. Tan, Z., D. Dini, F. Rodriguez y Baena, and A. E. Forte. Composite hydrogel: A high fidelity soft tissue mimic for surgery. Mater. Des. 160:886-894, 2018.

134. Tang, B., G. B. Hanna, and A. Cuschieri. Analysis of errors enacted by surgical trainees during skills training courses. Surgery 138:14-20, 2005.

135. Thomson, J. A. Embryonic stem cell lines derived from human blastocysts. Science (80-. ). 282:1145-1147, 1998.

136. Tibbits, S. 4D printing: Multi-material shape change. Archit. Des. 84:116-121, 2014.

137. Tseng, M. L., P. C. Wu, S. Sun, C. M. Chang, W. T. Chen, C. H. Chu, P. L. Chen, L. Zhou, D. W. Huang, T. J. Yen, and D. P. Tsai. Fabrication of multilayer metamaterials by femtosecond laser-induced forward-transfer technique. Laser Photonics Rev. 6:702-707, 2012.

138. Vaneker, T. H. J. The Role of Design for Additive Manufacturing in the Successful Economical Introduction of AM. Procedia CIRP 60:181-186, 2017.

139. Vermeulen, N., G. Haddow, T. Seymour, A. Faulkner-Jones, and W. Shu. 3D bioprint me: A socioethical view of bioprinting human organs and tissues. J. Med. Ethics 43:618-624, 2017.

140. Vijayavenkataraman, S., W. C. Yan, W. F. Lu, C. H. Wang, and J. Y. H. Fuh. 3D bioprinting of tissues and organs for regenerative medicine. Adv. Drug Deliv. Rev. 132:296-332, 2018.

141. Waldman, S. D. Pain Review E-Book. In: Elsevier Health Sciences. 2016.

142. Wang, P., H. C. Li, K. G. Prashanth, J. Eckert, and S. Scudino. Selective laser melting of Al-Zn-Mg-Cu: Heat treatment, microstructure and mechanical properties. J. Alloys Compd. 707:287-290, 2017.

143. Warnke, P. H., T. Douglas, P. Wollny, E. Sherry, M. Steiner, S. Galonska, S. T. Becker, I. N. Springer, J. Wiltfang, and S. Sivananthan. Rapid Prototyping: Porous Titanium Alloy Scaffolds Produced by Selective Laser Melting for Bone Tissue Engineering. Tissue Eng. Part C Methods 15:115-124, 2008.

144. Watson, R. A. A low-cost surgical application of additive fabrication. J. Surg. Educ. 71:14-17, 2014.

145. Weissleder, R. Scaling Down Imaging: Molecular Mapping of Cancer in Mice. Nat. Rev. Cancer 2:11-18, 2002.

146. Winder, J. A., and R. J. Bibb. Medical rapid prototyping technologies: state of the art and current limitations for application in oral and maxillofacial surgery. J. Oral Maxillofac. Surg. 63:245-248, 2005.

147. Witowski, J. S., M. Pędziwiatr, P. Major, and A. Budzyński. Cost-effective, personalized, 3D-printed liver model 
for preoperative planning before laparoscopic liver hemihepatectomy for colorectal cancer metastases. Int. J. Comput. Assist. Radiol. Surg. 12:2047-2054, 2017.

148. Wohlers, T. Rapid Prototyping \& Tooling State of the Industry: 1998 Worldwide Progress Report. Mater. Technol. 13:174-176, 2016.

149. Wong, K. V., and A. Hernandez. A Review of Additive Manufacturing. ISRN Mech. Eng. 2012:1-10, 2012.

150. Wurm, G., B. Tomancok, P. Pogady, K. Holl, and J. Trenkler. Cerebrovascular stereolithographic biomodeling for aneurysm surgery: Technical note. J. Neurosurg. 100:139-145, 2004.

151. Xu, T., J. Jin, C. Gregory, J. J. Hickman, and T. Boland. Inkjet printing of viable mammalian cells. Biomaterials 26:93-99, 2005.

152. Xu, T., H. Kincaid, A. Atala, and J. J. Yoo. High-throughput production of single-cell microparticles using an inkjet printing technology. J. Manuf. Sci. Eng. 130:021017, 2008.

153. Yang, D. H., J. W. Kang, N. Kim, J. K. Song, J. W. Lee, and T. H. Lim. Myocardial 3-dimensional printing for septal myectomy guidance in a patient with obstructive hypertrophic cardiomyopathy. Circulation 132:300-301, 2015.

154. Yang, H., S. Yang, X. Chi, and J. R. Evans. Fine ceramic lattices prepared by extrusion freeforming. Journal of Biomedical Materials. Res. Part B Appl. Biomater. An Off. J. Soc. Biomater. Japanese Soc. Biomater. Aust. Soc. Biomater. Korean Soc. Biomater. 79:116-121, 2006.

155. Yang, Y., L. Li, and J. Zhao. Mechanical property modeling of photosensitive liquid resin in stereolithography additive manufacturing: Bridging degree of cure with tensile strength and hardness. Mater. Des. 162:418-428, 2019.

156. Yang, Y., J. Bin Lu, Z. Y. Luo, and D. Wang. Accuracy and density optimization in directly fabricating customized orthodontic production by selective laser melting. Rapid Prototyp. J. 18:482-489, 2012.

157. Yeo, M. G., J. S. Lee, W. Chun, and G. H. Kim. An Innovative Collagen-Based Cell-Printing Method for Obtaining Human Adipose Stem Cell-Laden Structures Consisting of Core-Sheath Structures for Tissue Engineering. Biomacromolecules 17:1365-1375, 2016

158. Yogesh K Mariappan, K. J. Glaser, and R. L. Ehman. Magnetic resonance elastography: a review. Clin Anat 23:497-511, 2011

159. Yu, Y., and I. T. Ozbolat. Tissue strands as "bioink" for scale-up organ printing. 2014 36th Annu. Int. Conf. IEEE Eng. Med. Biol. Soc. EMBC 2014 1428-1431, 2014.doi:10.1109/EMBC.2014.6943868

160. Zhao, Y., Y. Li, S. Mao, W. Sun, and R. Yao. The influence of printing parameters on cell survival rate and printability in microextrusion-based 3D cell printing technology. Biofabrication 7:45002, 2015.

161. ASTM, I. (2015). ASTM52900-15 Standard Terminology for Additive Manufacturing-General PrinciplesTerminology. ASTM International, West Conshohocken, PA.

162. In Reply: BEHAVIOUR THERAPY. 1966, 211-212 pp.

163. STERILIZATION OF FDM-MANUFACTURED PARTS Mireya Perez. 285-296, 2012. 